\title{
Operational evaluation of the Mediterranean Monitoring and Forecasting Centre products: implementation and results
}

M. Tonani ${ }^{1}$, J. A. U. Nilsson ${ }^{1,{ }^{*}}$, V. Lyubartsev ${ }^{2}$, A. Grandi $^{1}$, A. Aydogdu $^{3}$, J. Azzopardi ${ }^{4}$, G. Bolzon ${ }^{5}$, A. Bruschi ${ }^{6}$, A. Drago ${ }^{4}$, T. Garau $^{7}$, J. Gatti ${ }^{8}$, I. Gertman $^{9}$, R. Goldman ${ }^{9}$, D. Hayes ${ }^{10}$, G. Korres ${ }^{11}$, P. Lorente ${ }^{12}$, V. Malacic ${ }^{13}$, A. Mantziafou ${ }^{14}$, G. Nardone ${ }^{6}$, A. Olita ${ }^{15}$, E. Ozsoy ${ }^{3}$, I. Pairaud ${ }^{16}$, S. Pensieri ${ }^{17}$, L. Perivoliotis ${ }^{11}$, B. Petelin ${ }^{13}$, M. Ravaioli ${ }^{18}$, L. Renault ${ }^{7}$, S. Sofianos ${ }^{14}$, M. G. Sotillo ${ }^{12}$, A. Teruzzi ${ }^{5}$, and G. Zodiatis ${ }^{10}$

${ }^{1}$ Istituto Nazionale di Geofisica e Vulcanologia, Bologna, Italy

${ }^{2}$ Centro euroMediterraneo per i Cambiamenti Climatici, Bologna, Italy

${ }^{3}$ Institute of Marine Sciences, Middle East Technical University, Turkey

${ }^{4}$ University of Malta, Physical Oceanography Unit, Malta

${ }^{5}$ Istituto Nazionale di Oceanografia e Geofisica Sperimentale, Trieste, Italy

${ }^{6}$ Istituto Superiore per la Protezione e la Ricerca Ambientale, Roma, Italy

${ }^{7}$ SOCIB, Balearic Islands Coastal Ocean Observing and Forecasting System,

Palma de Mallorca, Spain

Mediterranean Monitoring and

Forecasting Centre products

M. Tonani et al.

\section{Title Page}

\section{Full Screen / Esc}

Printer-friendly Version

Interactive Discussion 
${ }^{8}$ IFREMER, DYNECO-PHYSED, France

${ }^{9}$ Israel Oceanographic and Limnological Research, Haifa, Israel

OSD

${ }^{10}$ Oceanography Centre, University of Cyprus, Cyprus

${ }^{11}$ Hellenic Centre for Marine Research, Athens, Greece

${ }^{12}$ Puertos del Estado, Madrid, Spain

${ }^{13}$ National Institute of Biology, Slovenia

${ }^{14}$ University of Athens, Ocean Physics and Modelling Group, Athens, Greece

${ }^{15}$ Consiglio Nazionale delle Ricerche, Istituto per l'Ambiente Marino Costiero, Oristano, Italy

${ }^{16}$ IFREMER, LER PAC, France

${ }^{17}$ Consiglio Nazionale delle Ricerche, Istituto di Studi sui Sistemi Intelligenti per l'Automazione, Genova, Italy

${ }^{18}$ Consiglio Nazionale delle Ricerche, Istituto di Scienze Marine, Bologna, Italy

"now at: Climate Modeling Impacts Lab (UTMEA-ENEA), Roma, Italy

Received: 1 March 2012 - Accepted: 24 March 2012 - Published: 20 April 2012

Correspondence to: M. Tonani (marina.tonani@bo.ingv.it)

Published by Copernicus Publications on behalf of the European Geosciences Union.

\section{Mediterranean \\ Monitoring and \\ Forecasting Centre products}

M. Tonani et al.

Title Page

Abstract

Conclusions

Tables

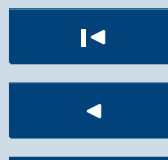

Back

Full Screen / Esc

Printer-friendly Version

Interactive Discussion 


\section{Abstract}

A web-based validation platform has been developed at the Istituto Nazionale di Geofisica e Vulcanologia (INGV) for the Near Real Time validation of the MyOceanMediterranean Monitoring and Forecasting Centre products (Med-MFC).

5 A network for the collection of the in-situ observations, the nested sub-basin forecasting systems model data (provided by the partners of the Mediterranean Operational Oceanography Network, MOON) and the Sea Surface Temperature (SST) satellite data has been developed and is updated every day with the new available data. The network collects temperature, salinity, currents and sea level data. The validation

\section{produced for the Mediterranean Sea.}

All the data are organized in an ad hoc database interfaced with a dedicated software which allows interactive visualizations and statistics (CalVal SW). This tool allows to evaluate NRT products by comparison with independent observations for the first time.

The heterogeneous distribution and the scarcity of moored observations reflect with large areas uncovered with measurements. Nevertheless, the evaluation of the forecast at the locations of observations could be very useful to discover sub-regions where the model performances can be improved, thus yielding an important complement to the basin-mean statistics regularly calculated for the Mediterranean MFC products using semi-independent observations.

\section{Introduction}

In order to allow Near Real-Time (NRT) quality and consistency controls of the Mediterranean Monitoring and Forecasting Centre (Med-MFC) products, a web-based validation system was developed at the National Institute of Geophysics and Vulcanology (INGV) within the framework of the European MyOcean project in collaboration with the Mediterranean Operational Oceanography Network (MOON) partners. A network

\section{OSD}

$9,1813-1851,2012$

\section{Mediterranean \\ Monitoring and \\ Forecasting Centre products}

M. Tonani et al.

\section{Title Page}

\section{Full Screen / Esc}

Printer-friendly Version

Interactive Discussion 
of 15 centers from 9 different countries was established for NRT data exchange purposes, which yielded the possibility to undertake on-line evaluations of the Med-MFC products using independent observational data along with the output from the nested sub systems in the Mediterranean Sea.

5 The first step was to create a network for the NRT collection at INGV of in-situ and remote-sensing observational data, as well as sub-regional ocean forecast fields. All the data are downloaded and processed on a daily basis by the operational center at INGV. The post-processing procedures involve a reorganization of the data sets according to their observational or model origin, and a subsequent storage in a common 10 MySQL database.

Due to this database, it has been possible to create a dedicated validation web page, http://gnoo.bo.ingv.it/myocean/calval which offers daily updated "on-fly" (qualitative and quantitative) quality checks of both forecasted and analyzed model fields by direct model-to-model or model-to-observation comparisons. Upon user request,

this wite communicates dynamically with database and provides diagnostics of the temperature, salinity, sea level, and velocity fields using the available observations and visualizes the results on-line.

The database allows also delay time (DT) products evaluation based upon ad-hoc defined statistics.

20 The validation of the biogeochemical products is limited by the scarce access to realtime high-quality observations. At present, this validation activity is performing NRT quality checks using satellite-deduced chlorophyll estimates for the Mediterranean Sea, as well as for eight sub-regions: Alboran Sea, North-West Mediterranean, South-West Mediterranean, Thyrrenian Sea, Southern Adriatic Sea, Ionian Sea, Aegean Sea and

Levantine Basin. MyOcean OC-TAC (Ocean Colour Thematic Assembly Centre) provides the satellite data used for the validation of the chlorophyll fields. This evaluation is available on the web (http://gnoo.bo.ingv.it/myocean/calval/bgc).

The present paper is organized as follows: Sect. 2 provides an overview of the MedMFC, Sect. 3 describes the Near Real Time data management, Sect. 4 describes the
OSD

9, 1813-1851, 2012

\section{Mediterranean \\ Monitoring and \\ Forecasting Centre products}

M. Tonani et al.

Title Page 
"CalVal SW", the applied metrics and the main web-site functions, Sect. 5 discusses the application and the results of the CalVal SW, the conclusions are in Sect. 6. Appendix A describes the technical details on the organization of the database, while Appendix $B$ details the informatics involved in the validation software and its main components.

\section{The Mediterranean Monitoring and Forecasting system}

The Med-MFC system is composed by three different components:

- Med-currents nominal production /dissemination unit;

- Med-biogeochemistry production/dissemination unit;

- Med-current back-up production/dissemination unit.

10 The three components are developed and maintained respectively by INGV, OGS and HCMR.

The numerical model component of Med-currents is composed by two elements: an Ocean General Circulation Model (OGCM) and a Wave Model. The OGCM code is NEMO-OPA (Nucleus for European Modelling of the Ocean-Ocean Parallelise) ver15 sion 3.2 (Madec et al., 2008). The code is developed and maintained by the NEMOconsortium. The model is primitive equation in spherical coordinates. The Wave Model is based on the WAM (Wave Analysis Model)-cycle 4 code (Kommen et al., 1994). NEMO-OPA has been implemented in the Mediterranean at $1 / 16 \times 1 / 16^{\circ}$ horizontal resolution and 71 unevenly spaced vertical levels (Oddo et al., 2009). The off-line coupling between NEMO and WAM is done as follow. The NEMO model provides a first guess of SST and surface currents, which are used by the WAM model. The neutral drag coefficient computed by WAM is used by the NEMO model and modified in order to take into account the stability conditions at the air-sea interface. The two models cover the entire Mediterranean Sea and also extend into the Atlantic in order to better resolve the exchanges with the Atlantic Ocean at the Strait of Gibraltar.
OSD

$9,1813-1851,2012$

\section{Mediterranean \\ Monitoring and \\ Forecasting Centre products}

M. Tonani et al.

Title Page

Abstract

Introduction

Conclusions

References

Tables

Figures

14

4

Back

Close

Full Screen / Esc

Printer-friendly Version

Interactive Discussion

- I .

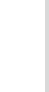

.

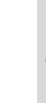


The wave model takes into consideration the surface currents for wave refraction but assumes no interactions with the ocean bottom. The model uses 24 directional bins $\left(15^{\circ}\right.$ directional resolution) and 30 frequency bins (ranging between $0.05 \mathrm{~Hz}$ and $0.7931 \mathrm{~Hz}$ ) to represent the wave spectra distribution.

5 The hydrodynamic model is nested, in the Atlantic, within the monthly mean climatological fields computed from ten years of daily output of the $1 / 4 \times 1 / 4^{\circ}$ degrees global model (Drevillon et al., 2008). Details on the nesting technique and major impacts on the model results are in Oddo et al. (2009). The model uses vertical partial cells to fit the bottom depth shape.

10 The model is forced by momentum, water and heat fluxes interactively computed by bulk formulae using the $6-\mathrm{h}, 0.25^{\circ}$ horizontal-resolution operational analysis and forecast fields from the European Centre for Medium-Range Weather Forecasts (ECMWF) and the model predicted surface temperatures (details of the air-sea physics are in Tonani et al., 2008). The water balance is computed as Evaporation minus Precipitation and Runoff. The evaporation is derived from the latent heat flux while the precipitation and the runoff are provided by monthly mean datasets: the Climate Prediction Centre Merged Analysis of Precipitation (CMAP) Data (Xie and Arkin, 1997); the Global Runoff Data Centre dataset (Fekete et al., 1999) for the Ebro, Nile and Rhone and the dataset from Raicich (Raicich, 1996) for the Adriatic rivers (Po, Vjosë, Seman and Bojana). The Dardanelles inflow is parameterized as a river and the climatological net inflow rates are taken from Kourafalou and Barbopoulos (2003). The data assimilation system is the OCEANVAR scheme developed by Dobricic and Pinardi (2008). The background error correlation matrix is estimated from the temporal variability of parameters in a historical model simulation. Background error correlation matrices vary seasonally and in 13 regions of the Mediterranean Sea, which have different physical characteristics (Dobricic et al., 2006). The mean dynamic topography used for the assimilation of SLA (Sea Lvel Anomaly) has been computed by Dobricic et al. (2005). The assimilated data include: sea level anomaly, sea surface temperature, in situ temperature profiles by VOS XBTs (Voluntary Observing Ship-eXpandable Bathythermograph), in situ temperature and

\section{OSD}

$9,1813-1851,2012$

\section{Mediterranean \\ Monitoring and \\ Forecasting Centre products}

M. Tonani et al.

Title Page

4 
salinity profiles by argo floats, and in situ temperature and salinity profiles from CTD (Conductivity-Temperature-Depth). Satellite OA-SST (Objective Analyses-Sea Surface Temperature) data are used for the correction of surface heat fluxes with the relaxation constant of $40 \mathrm{~W} \mathrm{~m}^{-2} \mathrm{~K}^{-1}$.

5 Med-biogeochemistry is off-line coupled to Med-currents, which provides the physical forcing in terms of velocity, temperature, salinity, irradiance, eddy diffusivity and wind speed fields (Teruzzi et al., 2011; Lazzari et al., 2010). The OPATM-BFM model of Med-biogeochemistry is a transport-reaction model that deals with the time evolution of chemical and biological state variables in the marine environment. It is based on the 10

Flux Model (BFM; Vichi et al., 2007a, b), an evolution of ERSEM (European Regional Sea Ecosystem Model). BFM is based on fluxes of elements (carbon, phosphorous, nitrogen and others) among chemical functional families and living functional groups. BFM is targeted on the phytoplankton/nutrients and microbial loop trophic level. Key as15 pects of the BFM are its potential for limitation by macronutrients (nitrogen, phosphate and silicate), the use of adjustable $\mathrm{C}: \mathrm{N}: \mathrm{P}: \mathrm{Si}$ ratios in zooplankton and phytoplankton compartments, and the chlorophyll to carbon variable dependency.

The Med-biogeochemistry provides 10 days of forecast preceded by 7 days of simulation driven by (a) physical forcings extracted by the analyses produced by the INGV Med-MFC_Current system, and (b) assimilation of available surface chlorophyll field derived by satellite observations at the first day of such simulation.

The assimilation is made by means of a 3DVAR scheme which uses the method of the error covariance matrix decomposition described in Dobricic and Pinardi (2008). In particular, the approach provides that the error covariance matrix is decomposed in a 25 series of different operators ( $\mathrm{Vi}$ ), and that the assimilation solution is found in a reduced dimension space (control space). Then the solution for the state vector (biogeochemical variables) is obtained by the sequential application of the Vi operators.

The Med-currents component has a back-up production and dissemination unit based on a simplified version of Med-currents system without wave-currents coupling

\section{OSD}

$9,1813-1851,2012$

\section{Mediterranean \\ Monitoring and \\ Forecasting Centre products}

M. Tonani et al.

Title Page 
and data assimilation. The back-up system is initialized everyday from the nominal system initial conditions in order to avoid discontinuity between the products of the two production lines. The format of the products is the same in order to reduce as much as possible the impact on the users. The back-up products are released only in case of 5 major failure of the nominal production. MyOcean Service Desk provides to the users all the needed information and support to switch to the back-up products in case of unavailability of the nominal products.

\subsection{Med-MFC products}

Every day $(J)$ the Med-currents system produces 10 days of forecast from $J$ to $J+9$ 10 (Tonani et al., 2010).

On Tuesday, 15 days of analyses are produced, from $J-15$ to $J-1$, with the assimilation of all the available satellite and in situ data. Med-biogeochemistry 10-day forecast is produced bi-weekly on Tuesday and on Friday.

All days but Tuesday a 24-h simulation is computed (from $J-1$ to $J$ ) in order to of forecast produced the previous day $(J-1)$ for the atmospheric forcing which is an analysis field instead of a forecast.

Med-biogeochemistry instead as a bi-weekly production of ten-day forecast which is initialized by seven days of analysis into the past.

Med-currents products are:

- Sea Level;

- Temperature;

- Salinity;

- Horizontal currents;
OSD

9, 1813-1851, 2012

\section{Mediterranean \\ Monitoring and \\ Forecasting Centre products}

M. Tonani et al.

Title Page

Abstract

Introduction

Conclusions

References

Tables

Figures

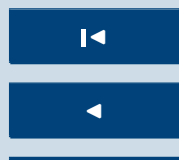

$>1$

Back

Close

Full Screen / Esc

Printer-friendly Version

Interactive Discussion 
- Wave Number.

Med-biogeochemistry products are:

OSD

- Chlorophyll;

9, 1813-1851, 2012

- Nutrients;

- Dissolved Oxygen concentration;

- Primary production;

- Phytoplankton biomass.

\section{Mediterranean \\ Monitoring and \\ Forecasting Centre products}

M. Tonani et al.

Even though the model has an extension into the Atlantic Ocean, the system delivers to the users only the Mediterranean Sea fields. The Atlantic region is not therefore 10 included in this NRT evaluation system. The products are available to the users as soon as they are produced and time series of the analysis fields are available for the past years. The users can therefore select the time frame of the datasets and also if needed the geographical sub-domain.

All the products are validated and assessed in Near Real Time (NRT) via comparison 15 with independent and semi-independent observations (Tonani et al., 2009). This study is focused on the Near Real Time validation with independent observations.

\section{The Near Real-Time Cal Val management}

The main purpose of the CalVal network is the collection of all the available moored buoys in the Mediterranean Sea for Med-MFC products validation. The MOON partners are therefore connected to the INGV collection centre in order to provide in NRT all observations and MOON nested sub-systems data extracted at the buoys location. Some partners deliver the data via the MyOcean INS-TAC Mediterranean Portal (IN SITU-Thematic Assembly Centre). In this case INGV collects the data directly from

Title Page

Abstract Introduction

Conclusions

References

Tables

Figures

14

4

Back

Close

Full Screen / Esc

Printer-friendly Version

Interactive Discussion

$>1$

$\triangleright$

Esc 
the Med-Portal. The setup of this network has been the first step of this work and it is presented in Fig. 1. NRT access to the in-situ observations and sub-regional ocean forecasts (cf. Fig. 2) was established by FTP protocols between INGV and the collaborating institutes (cf. Tables 1 and 2) or between INGV and INS-TAC, and the data are 5 presently being downloaded daily in operational mode.

After retrieval, all data are re-organized in a pre-determined table structure and saved in comma-separated variable (CSV) format, which thereafter can be directly imported in the MySQL database (see Fig. 3). Details on the MySQL database are in Appendix A. Moreover, relevant model and satellite estimates are calculated for the in-situ loca10 tions and stored correspondingly in the database. All the information collected in the database, see Fig. 3, are elaborated by an ad hoc-software in order to evaluate the quality of the Med-MFC products.

\subsection{Operational data flow}

The daily upload of data, format conversion, population of the MySQL data base and 15 update of the web interface is executed by a shell script and, in particular, this routine contains the following actions: (1) upload and convert in the standard format the insitu data, (2) update the in-situ locations, (3) retrieve the model values for in-situ and SST comparisons at in-situ data location, (4) upload the satellite SST data produced by the MyOcean SST-TAC L4 product for the Mediterranean Sea (Marullo et al., 2007)

20 at in-situ location, (5) populate the MySQL data base, (6) perform time aggregation of the in-situ data (Daily: 12 midday-12 midday, and night time: 00:00-04:00 for SST comparisons), (7) run Java-script to update the web page, and finally (8) update the in-situ meta data.

The operation described at point (6) is needed because the model data are $24 \mathrm{~h}$ 25 means average centred at midnight. The daily data flow is schematically described by Fig. 3, and some details on the actions dealing with the data post-processing and storage will be given in the following subsections.

\section{OSD}

$9,1813-1851,2012$

\section{Mediterranean \\ Monitoring and \\ Forecasting Centre products}

M. Tonani et al.

\section{Title Page}

\section{Full Screen / Esc}

Printer-friendly Version

Interactive Discussion 


\subsection{Data post-processing}

The Med-MFC produces daily 10-day forecasts, but here we evaluate only the third day-of- forecast, i.e. the forecast for day $J=0$ produced three days earlier (on $J=$ -3). Hence, the "forecast time series" is constructed by a continuous concatenation 5 of the third day-of-forecast values. This was done in order to evaluate the forecast degeneration after three days compared to the corresponding analyzed values.

The model data, both forecasts and analyses, as well as the SST satellite data, are interpolated linearly in the horizontal plane to each in-situ location, computing a weighted average among the four surrounding model nodes. Thereafter the horizontally 10 interpolated model values are bi-linearly interpolated to each respective sensor depth. In some special cases, the in-situ sensors are located partially or completely at the border of the Med-MFC model domain (close to the coast or to islands). It was decided, after some sensitivity tests, that if 2-3 model nodes are available, then the model data will be calculated as weighted averages between these grid points. If the in-situ sensor

15 is outside of the domain, then the observation will be compared to the model value from the nearest node. Figure 4 provides an example for the Mykonos station (HCMR, Greece), for the case of less than four neighbouring model grid nodes.

The data from the sub-regional ocean forecasting systems are interpolated to the in-situ locations by the data provider themselves upon their own interpolation routines. Hence there is no need for extra post-processing of these data sets.

\section{The web-based evaluation system}

The main functions of the validation tool are presented in Fig. 3, and the web site can also be accessed directly over the URL http://gnoo.bo.ingv.it/myocean/calval/. The map of the Mediterranean Sea indicates the positions of all in-situ stations; see Table 1 25 and Fig. 2. The default mode is set to "Buoy time series", see Fig. 4, but there is also the option "Buoy profiles" with some possibility to evaluate the vertical structure of the

OSD

9, 1813-1851, 2012

\section{Mediterranean \\ Monitoring and \\ Forecasting Centre products}

M. Tonani et al.

\section{Title Page}

\section{Full Screen / Esc}

Printer-friendly Version

Interactive Discussion 
modelled temperature, salinity and velocity fields. Only seven buoys vertical profiles for temperature, five for salinity and two for currents are currently available for this purpose. The "Buoy time series" has the possibility to select the year and the month of the time series while for the "Buoy profile" the selection is for year, month and day.

5 The selection of the variable that you choose to validate is the first step. The variables could be selected out of a pool of seven: Temperature, Salinity, Sea Level, Zonal Current, Meridional Current, Currents and Sea Surface Temperature. The CalVal SW compares, for the selected variable, up to three different data sources selected out of a list of thirteen: in situ daily mean, MFC-currents V1/V2 AN and FC 3d, Satellite OA10 SST, ALERMO FC, ALERMO AN, SCRM AN, POSEIDON FC, CYCOFOS FC, WMRM AN, SELIPS FC, ROSARIO FC and NAPON FC. The request options (Data sources 1, 2 and 3 ), located to the left of the map, work as automatic filters of the "data sources", and "organisations" tables, and the "matching" data sets are listed below under "Buoys" along with the available in-situ sensor depths. The data from the selected station will appear as either time series or a vertical profile below the map along with root- meansquare errors (RMSE) and bias diagnostics, moreover, some useful information of the in-situ station and its sensors is provided to the right.

\subsection{Metrics}

In order to evaluate and assure the quality of the Med-MFC's products in a relatively 20 standardized manner, metrics were calculated in agreement with the proposed and established diagnostics within framework of the Marine Environment and Security for the European Area (MERSEA) project (Desaubier, 2006). In particular, the validation system is based on the so-called MERSEA "Class-2" and "Class-4" diagnostics, which imply direct model-to-model and model-to-observation comparisons. All confrontations

are undertaken from an "in-situ point-of-view", where the observational data are kept on their original grid, and the corresponding model (or satellite) estimates are interpolated to the sensor positions, as described in Sect. 3.2. The deviations between the data sets are quantified in terms of RMSE (Root Mean Square Error) and bias, where
OSD

9, 1813-1851, 2012

\section{Mediterranean \\ Monitoring and \\ Forecasting Centre products}

M. Tonani et al.

\section{Title Page}

\section{Full Screen / Esc}

Printer-friendly Version

Interactive Discussion 
the RMSE provide estimates of the model precision while the bias indicate possible systematically errors in the model forecasts and analyses, under the assumption that the observational data is correct. The mathematic formulations of these diagnostics are given in Eqs. (1) and (2):

$5 \operatorname{RMSE}\left(x_{\text {obs }}, x_{\text {mod } / \text { sat }}\right)=\sqrt{\left(\sum_{k=1}^{N}\left(x_{\text {mod } / \text { sat }}-x_{\text {obs }}\right)^{2} / N\right)}$

$\operatorname{bias}\left(x_{\text {obs }}, x_{\bmod / \mathrm{sat}}\right)=\sum_{k=1}^{N}\left(x_{\bmod / \mathrm{sat}}-x_{\text {obs }}\right) / N$

where $x_{\text {obs }}$ represents the observed in-situ value and $x_{\text {mod } / \text { sat }}$ the interpolated model or satellite estimate. The bias is always a difference: 2 nd data source minus 1 st data source, and 3rd data source minus 1st data sources. The in-situ observations are forced to be the 1st data source in the CalVal SW. The evaluated model variables, the supporting observations, and diagnostics are detailed in Table 3.

The sea-level validation is not as straight-forward as it may be for the other variables, since the model sea level anomalies cannot be confronted directly to the correspond15 ing observed estimates due to the common ocean-modelling assumption of sea-water incompressibility (i.e. the Boussinesq approximation), which implies that the volume rather than the mass is con- served. This type of generalization can easily be corrected for by post-processing of the three- dimensional mass fields. Here, Mediterraneanaverage steric height variations were calculated from the Med-MFC daily-mean temperature and salinity fields over a 10-yr period (in compliance with the methodology proposed by Mellor et al. (1995) for regional seas with open boundaries) from which a monthly climatology was subsequently computed. This is a new development and is still not operational in the CalVal SW but has been applied in the DT (Delay Time) evaluation compute from the dataset extracted from the database for the year 2011. Once
OSD

$9,1813-1851,2012$

\section{Mediterranean \\ Monitoring and \\ Forecasting Centre products}

M. Tonani et al.

Title Page

Abstract Introduction

Conclusions

References

Tables

Figures

14

4

Back

Close

Printer-friendly Version

Interactive Discussion 
this procedure will be fully tested will be operational in the CalVal SW. The CalVal SW in the operational version computes the mean sea level from the observation for the selected time period and subtracts it to the observation time series.

\subsection{Dynamic web-pages for validation purposes}

5 The plots and the corresponding diagnostics that are displayed on the webpage are created "on-fly", which implies that they are produced momentarily on demand. In particular, when the desired "datasources" have been selected, the web-page communicates with the MySQL data base through PHP-scripts, retrieves the relevant data, calculates the RMSE and bias, and visualizes the results using the object-oriented

10 JpGraph library (http://jpgraph.net/, created for PHP), see Appendix B.

Applying dynamically communicating web pages is a highly convenient method for making available information to a wide group of users, involving institutes located in different countries. The fact that the displayed plots are not pre-produced (static) images makes the validation tool most flexible, as the users can select independently what to compare at which location for a time period of their choice. Furthermore, since the data base is being updated daily by the operational chain there is no need for daily plot updates, since the data sets are always being retrieved on-fly thus yielding an almost autonomous validation system.

\section{Results and discussion}

20 Most of the sensor are located in the Mediterranean Sea surface layer ( $<100 \mathrm{~m}$ depth), see Table 1, thus the Med-MFC evaluation described in this study is largely focused on the evaluation of the analyses and forecasts representability of the ocean state above the mixed layer depth. Moreover the buoys distribution is unbalanced between the northern part of the basin and the southern with a lack of data along the southern
OSD

$9,1813-1851,2012$

\section{Mediterranean \\ Monitoring and \\ Forecasting Centre products}

M. Tonani et al.

\section{Title Page}

\section{Full Screen / Esc}

Printer-friendly Version

Interactive Discussion 
ocean even though the system is an open ocean system covering the entire Mediterranean basin. These limits must be kept in the right account and in spite of this the system is very powerful and has the potential to provide a large number of useful information.

5 A strength with this new validation tool is that it allows model evaluation in specific points since all forecasts and analyses are compared to local in-situ observation. Hence the system facilitates the discovery of sub-regions where the model performance could be improved, and thus yield an important complement to the basin-mean statistics that are regularly calculated for Med-MFC using semi-independent data (To10 nani et al., 2009).

\subsection{Efficiency of the network}

The number of the observations and sub-systems model data collected by the CalVal network have been evaluated for the year 2011 (see Fig. 5). Some buoys could be unavailable time to time due to maintenance or malfunctioning. The data flow at INGV is 5 constantly monitored in order to be able to detect problems, missing data or anomalous values. Every time a datum is missing or has unrealistic values INGV activates the contact point of reference in order to identify and record the problem.

Figure 5 top-panel shows the number of buoys available for each variable (temperature, salinity, sea level and current) as monthly means for year 2011. The number of 20 observations for temperature is around 30, for sea level around 25 while for currents and salinity the number decreases down to 15-10. These numbers are very important and should be taken into account for the evaluation of the overall statistics. The bottom panel represents the same statistic made for the nested sub-systems. Modifications of formats, failure in the production or delivery procedures could cause the 25 loss of data. These problems are now almost solved and robust automated operational procedures have been set up from both sides, INGV and the data providers. Most of the sub-systems have provided successfully the data even though at the end of the year some failures have been detected. These number should be taken into account if

\section{OSD}

$9,1813-1851,2012$

\section{Mediterranean \\ Monitoring and \\ Forecasting Centre products}

M. Tonani et al.

\section{Title Page}

\section{4}


a Delayed Time statistic is computed by inquiring directly the MySQL dataset without using the CalVal SW web interface as will be described in the following sub-section. A preliminary evaluation of the Med-MFC products based on the CalVal SW is presented in the following sub-sections. These are only examples of the potentiality intrinsic in 5 this instrument.

\subsection{Med-MFC-currents products evaluation}

\subsubsection{Sea level}

More than 20 tide gauges have been available during year 2011 (see Fig. 6). The majority of the available tide gauges are located in the western part of the basin along the Spanish coast, only few of them are in the eastern Mediterranean basin (see Fig. 2).

The differences between the model $\mathrm{AN}$ and $\mathrm{FC}-3 \mathrm{~d}$ are very small respect the error. The RMSE varies from ca. $10 \mathrm{~cm}$ (in February) to $3.6 \mathrm{~cm}$ in June, the annual mean is $6 \mathrm{~cm}$. These values are higher than the RMSE computed as basin mean with the semiindependent data (RMS of the misfi analysis-SLA data), Tonani et al. $(2009,2010)$ 15 (http://gnoo.bo.ingv.it/mfs/myocean/evaluation.html), which oscillates during the year between 4 and $3 \mathrm{~cm}$. The bias is close to zero for all the months of the year.

The time series for December 2011 at Tasuco buoy (IMS-METU) is shown in the bottom left-panel of Fig. 6 while the time series for February 2011 at Imperia location (ISPRA) is represented in the bottom right-panel of Fig. 6.

The model in both cases does not reproduce the full amplitude and variability of the signal. WMRM-AN (CNR-IAMC) at Imperia location has a lower error than MFC-AN, probably this is due to the higher grid resolution. seem not available to catch the entire amplitude and variability of the signal. The comparison between MFC-AN and WMRMAN at Imperia tide gauge shows a better quality for the nested sub-systems probably
OSD

9, 1813-1851, 2012

\section{Mediterranean \\ Monitoring and \\ Forecasting Centre products}

M. Tonani et al.

Title Page 


\subsubsection{Temperature}

The in-situ temperature observations at the depth interval from surface to $3 \mathrm{~m}$ depths, which correspond to the first model level, are around 27 for the year 2011 (see Fig. 7). The buoys are quite homogeneously distributed in the west and east Mediterranean 5 basin (see Fig. 2). The RMSE is of $1^{\circ} \mathrm{C}$ with a maximum in December $\left(1.2^{\circ} \mathrm{C}\right.$ ) and a minimum during July-August $\left(0.8^{\circ} \mathrm{C}\right)$. The $\mathrm{FC}-3 \mathrm{~d}$ has always a RMSE value higher than the $\mathrm{AN}$ and the difference between the two reaches its maximum during the summer time (July and August) with a difference around $0.2^{\circ} \mathrm{C}$. This result is in agreement with the degradation of the forecast studied in Tonani et al. (2009). At that time the 10 number of independent available observations was very low and therefore the evaluation has been done using the analysis field as reference field. The bias has seasonal variability with values less negative during the summer time. Med-MFC AN surface temperature is evaluated every week computing basin mean RMSE and bias between the model and the OA-SST (http://gnoo.bo.ingv.it/mfs/myocean/evaluation.html). The bias respects the statistics computed using the independent in-situ observations and the semi-independent OA-SST that could be mainly due to different spatial coverage of the two datasets, OA-SST covers all the model grid points. The comparisons between MFC-current AN and FC-3d for year 2011 with the observation of the Terragona buoy (Puertos del Estado) are in agreement with the statistics of the full year discussed above. The differences between AN and FC at this particular location are very small. The bias is slightly negative even though is clear from the figure that during the summer it is positive. The comparison between the MFC-currents-AN and ALERMO (NKUA) for year 2011 at the Phylos (HCMR) buoy location is shown in the bottom-right panel of Fig. 7. The RMSE at this location is higher that at Teragona, probably due to the high RMSE values during the summer. Alermo FC has a lower error than MFC-AN probably due to the higher resolution and different air-sea parameterization. The difference between both models and the observation during a couple of days ( 7 and 8 May) is very high and with a cold bias in both models. The model is able to represent the variability of

OSD

$9,1813-1851,2012$

\section{Mediterranean \\ Monitoring and \\ Forecasting Centre products}

M. Tonani et al.

\section{Title Page}


the signal during the summer but with a lower amplitude respect the observations. The geographical location of the buoys should be taken into consideration and somehow weighted in the statics at the basin level based upon these independent observations.

\subsubsection{Salinity}

5 The in situ observations for salinity as pointed out at the beginning of this session are quite few; for year 2011 only 10 buoys are available for the Mediterranean basin. Often the time series of these observations are discontinuous with several periods without data due to malfunctions of the sensor. The RMSE and bias for year 2011 for all the available buoys have been computed even if the number of observations is small (see

10 Fig. 8 upper panel) at the depth between surface and $3 \mathrm{~m}$. The bars indicate the number of buoys and the full line the RMSE (blue AN, red FC) and the dotted line the bias. The difference between $\mathrm{AN}$ and $\mathrm{FC}-3 \mathrm{~d}$ is very small, therefore the error of the model prevails on the degradation of the third-day forecast respect the analysis. The bias is always positive, therefore the model has an over estimation of the salt content even though as pointed out already for the temperature the bias could be negative at some buoys location as for example at Cabo de Palos (Puertos del Estado) during the month of July (bottom-left panel of Fig. 8). The model salinity at Capo the Palos in July 2011, has a different pattern than the in-situ values. The model underestimates the salinity except during a period of three days in the central part of the month. This variability 20 could be related to the dynamical characteristic of ocean circulation in this region and should be further investigate. The time series for the month of September at Lesvos (HCMR) location shows that the model has always a higher value of salinity with a quite high error. This could be due to the parameterization of the Dardanelles inflow in the Aegean sea. Med-MFC does not resolve the Dardanelles which are parameterized as 25 a river inflow using climatological values from Kourafallou et al. (2003). Probably this parameterization is not able to fully represent the variability of the salinity in this area.
OSD

$9,1813-1851,2012$

\section{Mediterranean \\ Monitoring and \\ Forecasting Centre products}

M. Tonani et al.

\section{Title Page}




\subsubsection{Currents}

The modelled velocity field is evaluated in a Eulerian context, that is, the measured velocity at a fixed location (by Acoustic Doppler Current Profilers, ADCP) is compared to interpolated model velocity estimates. The results can be presented in two different 5 ways, either divided in zonal and meridional velocity time series (along with RMSE and bias diagnostic), or as progressive vector diagrams (see Eq. 3).

$r(t)=\int_{0}^{T} v(t) \mathrm{d} t$

where $r$ described the trajectory, which is obtained by integration of the velocity $v$ in a fix point $(x, y)$ over a time interval $[0, T]$.

The calculated $r$ give an overview of direction and speed of the observed and modelled velocities and it is possible to immediately identify model inaccuracies such as for example too weak currents, but correct direct of the flow. The zonal and meridional velocities time series can indicate systematic errors, such as a continuously too week westerly flow, or too strong easterly flow.

Figure 9 shows the current evaluation for MFC-currents AN and POSEIDON FC at the Mikonos buoy location for October 2010. The zonal and meridional components time series for the in-situ and models are shown in the top panel of Fig. 9. None of the system, MFC-currents and POSEIDON are able to resolve the variability of the current field even though POSEIDON is very close to the buoy values for the first ten day of the month an the period between the 20 and the 24 of October. The RMSE is higher for both the model systems in the zonal component. The bias is negative for the zonal and positive for the meridional component, therefore the models underestimate the intensity in the zonal direction and overestimate in the meridional. Anyhow, it is clear in the bottom panel of Fig. 9 that the model is quite good for the direction but too week for the intensity.

OSD

$9,1813-1851,2012$

\section{Mediterranean \\ Monitoring and \\ Forecasting Centre products}

M. Tonani et al.

Title Page

Abstract Introduction

Conclusions

References

Tables

Figures

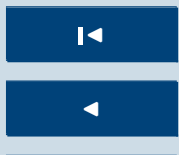

$>1$

Back

Close

Full Screen / Esc

Printer-friendly Version

Interactive Discussion 


\subsection{Med-MFC-biogeochemistry products evaluation}

At the web page http://gnoo.bo.ingv.it/myocean/calval/bgc/ the comparison between Med-MFC-biogeochemistry results and data derived by satellite observations is shown. The satellite data are processed by an algorithm appositely developed by the Mediter5 ranean Sea and the chlorophyll concentration results are provided by the MyOcean OC-TAC. The comparison is made in term of sea surface chlorophyll concentration for the whole Mediterranean Sea and for different sub-basins: ALB = Alboran Sea, SWM = south-western Mediterranean Sea, NWM = north-western Mediterranean Sea, TYR = Tyrrhenian Sea, ADS = southern Adriatic Sea, AEG = Aegean Sea, ION = Ionian 10 Sea, LEV = Levantine basin). Since the OPATM-BFM is a pelagic model, only the area with sea depth grater than $200 \mathrm{~m}$ are considered for the statistics evaluation. Figure 10 provides an example of the comparison for 2011 for the Mediterranean Sea and for the Tyrrhenian Sea and Levantine basin. The version of the forecasting system operational in year 2011 which produced the above discussed data did not have the data assimilation component. This latter was activated in January 2012.

In Fig. 10 the 25th, 50th and 75th percentiles are shown as well as the minimum and maximum values. The model reproduces the seasonal behaviour of chlorophyll concentration (low values during summer and high values during winter), but at the same time it shows overestimation of the values in winter and underestimation in summer for the percentiles. Furthermore, the maximum values are generally underestimated, and in particular in the Tyrrhenian Sea. The minimum is also underestimated, but it is worth to note that the algorithm adopted to evaluate the chlorophyll concentration from satellite data does not take into account values lower than $0.01 \mathrm{mg} \mathrm{m}^{-3}$. The model values are characterized by grater variability with respect to satellite results during spring decrease of chlorophyll concentration is significantly more pronounced than in the satellite time evolution.

OSD

$9,1813-1851,2012$

\section{Mediterranean \\ Monitoring and \\ Forecasting Centre products}

M. Tonani et al.

\section{Title Page}


In spite of the discussed drawbacks of the model, it is able to well capture phytoplankton bloom events (not shown here, for further details see Teruzzi et al., 2011). Moreover the introduction of the data assimilation in the Med-MFC-biogeochemistry system has improved the forecasting capability of the model.

\section{Conclusions}

The CalVal SW and network has been successfully designed and implemented. Most of the in-situ observations available for the Mediterranean Sea are connected to the network and used for validation purposes. The inter-comparison with the nested forecast sub-systems is a very powerful tool that has been only preliminary investigated 10 in this study. The assessment of the skill of the nested sub-systems respect the basin system could be easily done with this tool as well as the evaluation of the impacts of the basin scale system upgrades.

The system is flexible and could be extended with the addition of new in-situ and model data. The CalVal SW works operationally since year 2010 (with a major upgrade 15 in 2011) and additional functionalities could be introduced in the future. As soon as valuable in situ biogeochemical observations will be available the CalVal SW could be modified in order to take them into account.

\section{Appendix A}

\section{MySQL database}

20 The MySQL database is organized in terms a main table ("data") and connected subtables ("data sources", "devices", "organisations", "probes", and "variables"), and the general structure of the database is illustrated in Fig. 3. The main ("data") table is constructed by the three sub tables: "datasources", "probes" and "variables", where the "probes-table" is structured by the "organisations" and "devices" tables.

1833

\section{OSD}

$9,1813-1851,2012$

\section{Mediterranean \\ Monitoring and \\ Forecasting Centre products}

M. Tonani et al.

\section{Title Page}

\section{Full Screen / Esc}

Printer-friendly Version

Interactive Discussion 
When the daily uploading/conversion procedure of in-situ, satellite and model data is completed the data is stored in a CSV table. In order to assure the uniqueness of each value and not risking "over-writing" of previously imported values, each sub-table was associated with an identification number to keep the database in sound order.

5 The datasource id indicates the origin of the data (in-situ, satellite, model forecast or analysis), and the variable_id sorts the variables (temperature, SST, salinity, sea level, or currents) obtained from or retrieved for each in-situ location. Moreover, all locations are identified by probe_id numbers, which hold information such as the station name, its geographical coordinates, the type of sensor (device_id, e.g. moored buoy, profiler or

10 tide gauge), and the responsible organisation (organisation_id, i.e. the data providers, cf. Tables 1 and 2).

\section{Appendix B}

\section{CalVal SoftWare}

The CalVal SoftWare, CalVal SW, is based on the open-source software bundle LAMP 15 (acronym for Linux Apache Mysql Php) and an overview of its general architectural structure is provided in Fig. 3. The LAMP stack is widely used since it offers a great number of advantages for developers, as it is relatively easy to code and add new software features with PHP to the existing MySQL setup. PHP is a general-purpose scripting language that is especially suited for producing dynamic web pages; more-

over, it is a standard Linux component (http://www.php.net). The CalVal SW requires also the installation of NCAR Command Language (NCL) for data format conversion (NetCDF $\rightarrow$ ascii) in the post-processing routines. NCL is a free interpreted language designed specifically for scientific data processing and visualization, and can easily be installed on Linux platforms (cf. http://www.ncl.ucar.edu/overview.shtml).

$25 \quad$ MySQL is a relational database management system that runs as a server providing multi- user access to a number of databases (http://www.mysql.com/). Several other
OSD

9, 1813-1851, 2012

\section{Mediterranean \\ Monitoring and \\ Forecasting Centre products}

M. Tonani et al.

Title Page

Abstract

Introduction

Conclusions

References

Tables

Figures

14

4

Back

Close

Printer-friendly Version

Interactive Discussion 
third-party proprietary and free graphical administration applications, or "Front-ends", are available that integrate with MySQL and enable users to work with the database structure and the data visually. Here we have used the well-known web-based front-end phpMyAdmin (http://www.phpmyadmin.net/), since it is developed in PHP and compat5 ible with the LAMP stack.

Acknowledgements. This work was supported by the European Commission MyOcean Project (SPA.2007.1.1.01, development of upgrade capabilities for existing GMES fast-track services and related operational services, grant agreement 218812-1-FP7-SPACE 2007-1).

We thank Nadia Pinardi (University of Bologna, Italy) for valuable advice.

10 We thank the MyOcean SST-TAC, OC-TAC and INS-TAC for the provision of the satellite and in situ data.

The buoys data have been provided by: Consiglio Nazionale delle Ricerche, CNR (Italy); Consejo Superior de Investigaciones Cientificas, CSIC (Spain); Hellenic Centre for Marine Research, HCMR (Greece); Institute of Marine Sciences - Middle East Technical University, IMS-

15 METU (Turkey); Israel Oceanographic and Limnological Research, IOLR (Israel); Istituto Superiore per la Protezione e la Ricerca Ambientale, ISPRA (Italy); National Institute of Biology, NIB (Slovenia); Oceanography Centre-University of Cyprus, OC-UCY (Cyprus); Puertos del Estado (Spain), University of Malta-Physical Oceanography Unit, UMT-POU (Malta) and IFREMER (France).

\section{References}

Desaubies, Y.: Mersea, Development of a European Ocean Monitoring and Forecasting System - Ocean and Marine applications for Gmes, Ocean Weather Forecasting: An Integrated View of Oceanography, Chapter 19, 449-453, Springer, 2006.

Dobricic. S. and Pinardi, N.: An oceanographic three-dimensional variational data assimilation scheme, Ocean Modell., 22, 89-105, 2008.

Drevillon, M., Bourdalle-Badie, R., Derval, C., Drillet, Y., Lellouche, J. M., Remy, E., Tranchant, B., Benkiran, M., Greiner, E., Guinehut, V. N., Garric S. G., Testut, C. E., La-borie, M., Nouel, L., Bahurel, P., Bricaud, C., Crosnier, L., Dombrosky, E., Durand, E., Ferry, N., Hernandez,

\section{Mediterranean \\ Monitoring and \\ Forecasting Centre products}

M. Tonani et al.

Title Page

Abstract

Introduction

Conclusions

References

Tables

Figures

14

4

Back

Close

Full Screen / Esc

Printer-friendly Version

Interactive Discussion

$\rightarrow 1$

$x^{2}$ 
F., Le Galloudec, O., Messal, F., and Parent, L.: The GODAE/Mercator- Ocean global ocean forecasting system: results, applications and prospects, J. Operational Oceanogr., 1, 51-57, 2008.

Komen, G. J., Cavaleri, L., Donelan, M., Hasselman, K., Hasselman, S., and Janssen, P. A. E. $5 \quad$ M.: Dynamics and modelling of ocean waves. Cambridge University Press, Cambridge, UK, 532 pp., 1994.

Kourafalou, V. H. and Barbopoulos, K.: High resolution simulations on the North Aegean Sea seasonal circulation, Ann. Geophys., 21, 251-265, doi:10.5194/angeo-21-251-2003, 2003.

Lazzari, P., Teruzzi, A., Salon, S., Campagna, S., Calonaci, C., Colella, S., Tonani, M., and Crise, A.: Pre-operational short-term forecasts for Mediterranean Sea biogeochemistry, Ocean Sci., 6, 25-39, doi:10.5194/os-6-25-2010, 2010.

Le Traon, P. Y., Nadal, F., and Ducet, N.: An improved mapping method of multi- satellite altimeter data, J. Atmos. Ocean. Technol., 15, 522-533, 2003.

Madec, G., Delecluse, P., Imbard, M., and Levy, C.: Opa8.1 Ocean General Circulation Model 15 reference manual. Note du Pole de modelisazion, Institut Pierre-Simon Laplace (IPSL), France, 11, 1998.

Manzella, G. M. R., Reseghetti, F., Coppini, G., Borghini, M., Cruzado, A., Galli, C., Gertman, I., Gervais, T., Hayes, D., Millot, C., Murashkovsky, A., Özsoy, E., Tziavos, C., Velasquez, Z., and Zodiatis, G.: The improvements of the ships of opportunity program in MFS-TEP, Ocean

20 Sci., 3, 245-258, doi:10.5194/os-3-245-2007, 2007.

Marullo, S., Buongiorno Nardelli, B., Guarracino, M., and Santoleri, R.: Observing the Mediterranean Sea from space: 21 years of Pathfinder-AVHRR sea surface temperatures (1985 to 2005): re-analysis and validation, Ocean Sci., 3, 299-310, doi:10.5194/os-3-299-2007, 2007.

Mellor, G. and Ezer, T.: Sea level variations induced by heating and cooling: An evaluation of the Boussinesq approximation in ocean models, J. Geophys. Res., 100, 20565-20577, 1995.

Nittis, K., Perivoliotis, L., Korres, G., Tziavos, C., and Thanos, I.: Operational monitoring and forecasting for marine environmental applications in the Aegean Sea, Environ. Modell. Softw., 21, 243-257, doi:10.1016/j.envsoft.2004.04.023, 2006.

30 Oddo, P., Adani, M., Pinardi, N., Fratianni, C., Tonani, M., and Pettenuzzo, D.: A nested AtlanticMediterranean Sea general circulation model for operational forecasting, Ocean Sci., 5, 461473, doi:10.5194/os-5-461-2009, 2009.
OSD

$9,1813-1851,2012$

\section{Mediterranean \\ Monitoring and \\ Forecasting Centre products}

M. Tonani et al.

Title Page

Abstract

Introduction

Conclusions

References

Tables

Figures

14

4

Back

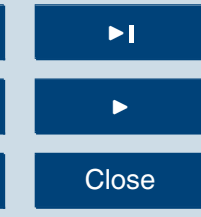

Full Screen / Esc

Printer-friendly Version

Interactive Discussion 
Poulain, P.-M., Barbanti, R., Font, J., Cruzado, A., Millot, C., Gertman, I., Griffa, A., Molcard, A., Rupolo, V., Le Bras, S., and Petit de la Villeon, L.: MedArgo: a drifting profiler program in the Mediterranean Sea, Ocean Sci., 3, 379-395, doi:10.5194/os-3-379-2007, 2007.

Raicich F.: Note on the flow rate of the Adriatic Rivers, CNR-Technical Report, 02, 1994.

5 Teruzzi, A., Salon, S., Bolzon, G., Lazzari, P., Campagna, S., Ficarelli, F., Solidoro, C., and Crise, A.: Operational forecast of the biogeochemical state of the Mediterranean Sea, Mercator ocean Newsletter, no. 40, 2011.

Tonani, M., Pinardi, N., Dobricic, S., Pujol, I., and Fratianni, C.: A high-resolution free-surface model of the Mediterranean Sea, Ocean Sci., 4, 1-14, doi:10.5194/os-4-1-2008, 2008.

Tonani, M., Pinardi, N., Fratianni, C., Pistoia, J., Dobricic, S., Pensieri, S., de Alfonso, M., and Nittis, K.: Mediterranean Forecasting System: forecast and analysis assessment through skill scores, Ocean Sci., 5, 649-660, doi:10.5194/os-5-649-2009, 2009.

Tonani, M., Pinardi, N., Adani, M., Bonazzi, A., Coppini, G., De Dominicis, M., Dobricic, S., Drudi, M., Fabbroni, N., Fratianni, C., Grandi, A., Lyubartsev, V., Oddo, P., Pettenuzzo, D., Pistoia, J., and Pujol, I.: The Mediterranean ocean Forecasting System, Coastal to Global Operational Oceanography: Achievements and Challenges, Proceedings of the Fifth International Conference on EuroGOOS 20-22 May 2008, Exeter, UK, edited by: Dahlin, H., EuroGOOS Office, Norrkoping, Sweden, Bell, M. J., Met Office, UK, Fleming, N. C., UK, Pietersson, S. E., EuroGOOS Office, Norrkoping, Sweden, EuroGOOS Publication, 1st Edn., 202010.

Vichi, M., Pinardi, N., and Masina, S.: A generalized model of pelagic biogeochemistry for the global ocean ecosystem, Part I: Theory, J. Mar. Sys., 64, 89-109, 2007a.

Vichi, M., Masina, S., and Navarra, A.: A generalized model of pelagic biogeochemistry for the global ocean ecosystem. Part II: Numerical Simulations, J. Mar. Sys., 64, 110-134, 2007b.

\section{OSD}

$9,1813-1851,2012$

\section{Mediterranean \\ Monitoring and \\ Forecasting Centre products}

M. Tonani et al.

Title Page

Abstract

Introduction

Conclusions

References

Tables

Figures

14

4

Back

Close

Full Screen / Esc

Printer-friendly Version

Interactive Discussion 
Table 1. List of the buoys providing NRT in-situ observations. Abbreviations: TG = Tide gauges, $\mathrm{MB}=$ Moored buoys, $\mathrm{ADCP}=$ Acoustic Doppler Current Profiler .

\begin{tabular}{|c|c|c|c|c|c|c|c|}
\hline Buoy name & Wmo & Lon & Lat & Frequency & Type & Depth (m) & Parameter \\
\hline $\mathrm{S} 1$ & & $12^{\circ} 27^{\prime} 26^{\prime \prime} \mathrm{E}$ & $44^{\circ} 44^{\prime} 35^{\prime \prime} \mathrm{N}$ & $1 \mathrm{~h}$ & MB & 1.6 & $T, S$ \\
\hline ODAS & 61010 & $9^{\circ} 06^{\prime} 42^{\prime \prime} \mathrm{E}$ & $43^{\circ} 49^{\prime} 35^{\prime \prime} \mathrm{N}$ & $3 \mathrm{~h}$ & MB & $\begin{array}{l}1,6,12,20,29,36 \\
6,20,36\end{array}$ & $\begin{array}{l}T \\
S\end{array}$ \\
\hline Enderrocat & & $2^{\circ} 42^{\prime} 02^{\prime \prime} \mathrm{E}$ & $39^{\circ} 29^{\prime} 49^{\prime \prime} \mathrm{N}$ & $1 \mathrm{~h}$ & MB & $\begin{array}{l}1,3,5,7,9,10,13,15,17,19 \\
10\end{array}$ & $\begin{array}{l}T \\
S\end{array}$ \\
\hline & & & & & $\mathrm{ADCP}$ & $1,9,19$ & Currents \\
\hline \multirow[t]{3}{*}{ Cabrera } & & $2^{\circ} 57^{\prime} 59^{\prime \prime} \mathrm{E}$ & $39^{\circ} 13^{\prime} 28^{\prime \prime} \mathrm{N}$ & $1 \mathrm{~h}$ & $\mathrm{MB}$ & $\begin{array}{l}1,3,5,7,9,10,11,13,15,17 \\
19,20\end{array}$ & $T$ \\
\hline & & & & & & 10 & $S$ \\
\hline & & & & & ADCP & $1,9,19$ & Currents \\
\hline Saronikos & & $23^{\circ} 33^{\prime} 49^{\prime \prime} \mathrm{E}$ & $37^{\circ} 36^{\prime} 02^{\prime \prime} \mathrm{N}$ & $3 \mathrm{~h}$ & $M B \& A D C P$ & 3 & $T, S$, Currents \\
\hline Zakynthos & & $20^{\circ} 36^{\prime} 13^{\prime \prime} \mathrm{E}$ & $37^{\circ} 56^{\prime} 48^{\prime \prime} \mathrm{N}$ & $3 \mathrm{~h}$ & $M B \& A D C P$ & 3 & $T, S$, Currents \\
\hline Santorini & & $25^{\circ} 29^{\prime} 46^{\prime \prime} \mathrm{E}$ & $36^{\circ} 15^{\prime} 43^{\prime \prime} \mathrm{N}$ & $3 \mathrm{~h}$ & $M B \& A D C P$ & 3 & $T, S$, Currents \\
\hline Mykonos & & $25^{\circ} 27^{\prime} 29^{\prime \prime} \mathrm{E}$ & $37^{\circ} 30^{\prime} 36^{\prime \prime} \mathrm{N}$ & $3 \mathrm{~h}$ & $M B \& A D C P$ & 3 & $T, S$, Currents \\
\hline Lesvos & & $25^{\circ} 48^{\prime} 46^{\prime \prime} \mathrm{E}$ & $39^{\circ} 09^{\prime} 28^{\prime \prime} \mathrm{N}$ & $3 \mathrm{~h}$ & $M B \& A D C P$ & 3 & $T, S$, Currents \\
\hline Athos & & $24^{\circ} 43^{\prime} 12^{\prime \prime} \mathrm{E}$ & $39^{\circ} 57^{\prime} 50^{\prime \prime} \mathrm{N}$ & $3 \mathrm{~h}$ & $\begin{array}{l}\mathrm{MB} \\
\mathrm{ADCP}\end{array}$ & $\begin{array}{l}1,20,50,75,100 \\
1\end{array}$ & $\begin{array}{l}T, S \\
\text { Currents }\end{array}$ \\
\hline \multirow[t]{2}{*}{ Pylos } & 68422 & $21^{\circ} 35^{\prime} 45^{\prime \prime} \mathrm{E}$ & $36^{\circ} 49^{\prime} 31^{\prime \prime} \mathrm{N}$ & $3 \mathrm{~h}$ & MB & $\begin{array}{l}1,20,50,75,100,250,400,500 \text {, } \\
1673\end{array}$ & $T, S$ \\
\hline & & & & & $\mathrm{ADCP}$ & 1 & Currents \\
\hline \multirow[t]{2}{*}{ E1-M3A } & 61277 & $24^{\circ} 55^{\prime} 12^{\prime \prime} \mathrm{E}$ & $35^{\circ} 46^{\prime} 42^{\prime \prime} \mathrm{N}$ & $3 \mathrm{~h}$ & $\mathrm{MB}$ & $\begin{array}{l}1,3,20,50,75,100,250,400 \\
600,1000\end{array}$ & $T, S$ \\
\hline & & & & & ADCP & $1,3,20,50$ & Currents \\
\hline Skyros & & $24^{\circ} 27^{\prime} 34^{\prime \prime} \mathrm{E}$ & $39^{\circ} 06^{\prime} 21^{\prime \prime} \mathrm{N}$ & $3 \mathrm{~h}$ & $M B \& A D C P$ & 3 & $T, S$, Currents \\
\hline Kalamata & & $22^{\circ} 05^{\prime} 44^{\prime \prime} \mathrm{E}$ & $36^{\circ} 58^{\prime} 19^{\prime \prime} \mathrm{N}$ & $3 \mathrm{~h}$ & $M B \& A D C P$ & 3 & $T, S$, Currents \\
\hline MesuRho & 61284 & $04^{\circ} 51^{\prime} 57^{\prime \prime} \mathrm{E}$ & $43^{\circ} 19^{\prime} 08^{\prime \prime} \mathrm{N}$ & $30 \mathrm{~min}$ & $\mathrm{MB}$ & 3 & $T, S$ \\
\hline Tasucu & & $33^{\circ} 50^{\prime} 09^{\prime \prime} \mathrm{E}$ & $36^{\circ} 16^{\prime} 53^{\prime \prime} \mathrm{N}$ & $15 \mathrm{~min}$ & TG & 0 & SSH \\
\hline Keryneia (Girne) & & $33^{\circ} 20^{\prime} 03^{\prime \prime} \mathrm{E}$ & $35^{\circ} 20^{\prime} 26^{\prime \prime} \mathrm{N}$ & $15 \mathrm{~min}$ & TG & 0 & SSH \\
\hline Hadera & & $34^{\circ} 51^{\prime} 46^{\prime \prime} \mathrm{E}$ & $32^{\circ} 28^{\prime} 14^{\prime \prime} \mathrm{N}$ & $1 \mathrm{~h}$ & ADCP & $\begin{array}{l}4.9,5.4,5.9,6.4,6.9,7.4,7.9, \\
8.4,8.9,9.4,9.9,10.4,10.9,11.4, \\
11.9,12.4,12.9,13.4,13.9,14.4, \\
14.9,15.4,15.9,16.4,16.9,17.4, \\
17.9,18.4,18.9,19.4,19.9,20.4, \\
20.9,21.4,21.9,22.4,22.9,23.4, \\
23.9,28.9\end{array}$ & Currents \\
\hline
\end{tabular}

OSD

$9,1813-1851,2012$

\section{Mediterranean \\ Monitoring and \\ Forecasting Centre products}

M. Tonani et al.

Title Page

Abstract

Introduction

Conclusions

References

Tables

Figures
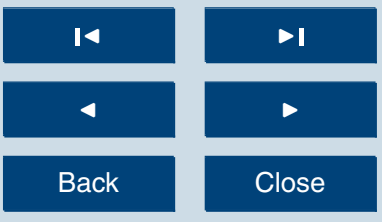

Back

Close

Full Screen / Esc

Printer-friendly Version

Interactive Discussion 
Table 1. Continued.

OSD

\begin{tabular}{|c|c|c|c|c|c|c|c|}
\hline Buoy name & Wmo & Lon & Lat & Frequency & Type & Depth (m) & Parameter \\
\hline Alghero & 61213 & $08^{\circ} 06^{\prime} 24^{\prime \prime} \mathrm{E}$ & $40^{\circ} 32^{\prime} 54^{\prime \prime} \mathrm{N}$ & $30 \mathrm{~min}$ & MB & 0 & $T$ \\
\hline Ancona & 61218 & $13^{\circ} 43^{\prime} 09^{\prime \prime} \mathrm{E}$ & $43^{\circ} 49^{\prime} 30^{\prime \prime} \mathrm{N}$ & $30 \mathrm{~min}$ & MB & 0 & $T$ \\
\hline Cagliari & 61221 & $09^{\circ} 24^{\prime} 17^{\prime \prime} \mathrm{E}$ & $39^{\circ} 06^{\prime} 54^{\prime \prime} \mathrm{N}$ & $30 \mathrm{~min}$ & MB & 0 & $T$ \\
\hline Catania & 61207 & $15^{\circ} 08^{\prime} 48^{\prime \prime} \mathrm{E}$ & $37^{\circ} 26^{\prime} 23^{\prime \prime} \mathrm{N}$ & $30 \mathrm{~min}$ & MB & 0 & $T$ \\
\hline Cetraro & 61211 & $15^{\circ} 55^{\prime} 00^{\prime \prime} \mathrm{E}$ & $39^{\circ} 27^{\prime} 02^{\prime \prime} \mathrm{N}$ & $30 \mathrm{~min}$ & MB & 0 & $T$ \\
\hline Civitavecchia & 61216 & $11^{\circ} 33^{\prime} 14^{\prime \prime} \mathrm{E}$ & $42^{\circ} 14^{\prime} 40^{\prime \prime} \mathrm{N}$ & $30 \mathrm{~min}$ & MB & 0 & $T$ \\
\hline Crotone & 61210 & $17^{\circ} 13^{\prime} 11^{\prime \prime} \mathrm{E}$ & $39^{\circ} 01^{\prime} 24^{\prime \prime} \mathrm{N}$ & $30 \mathrm{~min}$ & MB & 0 & $T$ \\
\hline La Spezia & 61219 & $09^{\circ} 49^{\prime} 40^{\prime \prime} \mathrm{E}$ & $43^{\circ} 55^{\prime} 45^{\prime \prime} \mathrm{N}$ & $30 \mathrm{~min}$ & MB & 0 & $T$ \\
\hline Mazara & 61208 & $12^{\circ} 31^{\prime} 59^{\prime \prime} \mathrm{E}$ & $37^{\circ} 31^{\prime} 05^{\prime \prime} \mathrm{N}$ & $30 \mathrm{~min}$ & MB & 0 & $T$ \\
\hline Monopoli & 61215 & $17^{\circ} 22^{\prime} 40^{\prime \prime} \mathrm{E}$ & $40^{\circ} 58^{\prime} 30^{\prime \prime} \mathrm{N}$ & $30 \mathrm{~min}$ & MB & 0 & $T$ \\
\hline Ortona & 61217 & $14^{\circ} 32^{\prime} 09^{\prime \prime} \mathrm{E}$ & $42^{\circ} 24^{\prime} 24^{\prime \prime} \mathrm{N}$ & $30 \mathrm{~min}$ & MB & 0 & $T$ \\
\hline Palermo & 61209 & $13^{\circ} 19^{\prime} 59^{\prime \prime} \mathrm{E}$ & $38^{\circ} 15^{\prime} 29^{\prime \prime} \mathrm{N}$ & $30 \mathrm{~min}$ & MB & 0 & $T$ \\
\hline Ponza & 61214 & $12^{\circ} 56^{\prime} 59^{\prime \prime} \mathrm{E}$ & $40^{\circ} 52^{\prime} 00^{\prime \prime} \mathrm{N}$ & $30 \mathrm{~min}$ & MB & 0 & $T$ \\
\hline Siniscola & 61212 & $09^{\circ} 53^{\prime} 30^{\prime \prime} \mathrm{E}$ & $40^{\circ} 37^{\prime} 00^{\prime \prime} \mathrm{N}$ & $30 \mathrm{~min}$ & MB & 0 & $T$ \\
\hline Venezia & 61220 & $12^{\circ} 31^{\prime} 00^{\prime \prime} \mathrm{E}$ & $45^{\circ} 20^{\prime} 00^{\prime \prime} \mathrm{N}$ & $30 \mathrm{~min}$ & MB & 0 & $T$ \\
\hline Carloforte & & $08^{\circ} 18^{\prime} 34^{\prime \prime} \mathrm{E}$ & $39^{\circ} 08^{\prime} 52^{\prime \prime} \mathrm{N}$ & $1 \mathrm{~h}$ & TG & 0 & SSH \\
\hline Imperia & & $08^{\circ} 01^{\prime} 07^{\prime \prime} \mathrm{E}$ & $43^{\circ} 52^{\prime} 42^{\prime \prime} \mathrm{N}$ & $1 \mathrm{~h}$ & TG & 0 & SSH \\
\hline Napoli & & $14^{\circ} 16^{\prime} 09^{\prime \prime} \mathrm{E}$ & $40^{\circ} 50^{\prime} 29^{\prime \prime} \mathrm{N}$ & $1 \mathrm{~h}$ & TG & 0 & SSH \\
\hline Otranto & & $18^{\circ} 29^{\prime} 49^{\prime \prime} \mathrm{E}$ & $40^{\circ} 08^{\prime} 49^{\prime \prime} \mathrm{N}$ & $1 \mathrm{~h}$ & TG & 0 & SSH \\
\hline Trieste & & $13^{\circ} 45^{\prime} 28^{\prime \prime} \mathrm{E}$ & $45^{\circ} 38^{\prime} 57^{\prime \prime} \mathrm{N}$ & $1 \mathrm{~h}$ & TG & 0 & SSH \\
\hline Venezia & & $12^{\circ} 25^{\prime} 35^{\prime \prime} \mathrm{E}$ & $45^{\circ} 25^{\prime} 05^{\prime \prime} \mathrm{N}$ & $1 \mathrm{~h}$ & TG & 0 & SSH \\
\hline VIDA & & $13^{\circ} 33^{\prime} 01^{\prime \prime} \mathrm{E}$ & $45^{\circ} 32^{\prime} 55^{\prime \prime} \mathrm{N}$ & $1 \mathrm{~h}$ & MB & 3 & $T, S$ \\
\hline & & & & & $\mathrm{ADCP}$ & $\begin{array}{l}2,3,4,5,6,7,8,9,10,11,12 \\
13,14,15,16,17,18,19,20\end{array}$ & Currents \\
\hline MedGOOS-3 & & $32^{\circ} 07^{\prime} 59^{\prime \prime} \mathrm{E}$ & $33^{\circ} 41^{\prime} 54^{\prime \prime} \mathrm{N}$ & $30 \mathrm{~min}$ & MB & $14,19,24,29,34$ & $T, S$ \\
\hline \multirow[t]{2}{*}{ Paphos } & & $32^{\circ} 24^{\prime} 29^{\prime \prime} \mathrm{E}$ & $34^{\circ} 45^{\prime} 18^{\prime \prime} \mathrm{N}$ & $30 \mathrm{~min}$ & MB & 3 & $T$ \\
\hline & & & & & TG & 0 & SSH \\
\hline Dragonera & 61430 & $02^{\circ} 06^{\prime} 06^{\prime \prime} \mathrm{E}$ & $39^{\circ} 33^{\prime} 17^{\prime \prime} \mathrm{N}$ & $1 \mathrm{~h}$ & $M B \& A D C P$ & 3 & $T, S$, Currents \\
\hline Tarragona & 61280 & $01^{\circ} 28^{\prime} 05^{\prime \prime} \mathrm{E}$ & $40^{\circ} 41^{\prime} 02^{\prime \prime} \mathrm{N}$ & $1 \mathrm{~h}$ & $M B \& A D C P$ & 3 & $T, S$, Currents \\
\hline Valencia & 61281 & $00^{\circ} 12^{\prime} 16^{\prime \prime} \mathrm{E}$ & $39^{\circ} 30^{\prime} 57^{\prime \prime} \mathrm{N}$ & $1 \mathrm{~h}$ & $M B \& A D C P$ & 3 & $T, S$, Currents \\
\hline Cabo de Palos & 61417 & $00^{\circ} 19^{\prime} 28^{\prime \prime} \mathrm{W}$ & $37^{\circ} 39^{\prime} 04^{\prime \prime} \mathrm{N}$ & $1 \mathrm{~h}$ & $M B \& A D C P$ & 3 & $T, S$, Currents \\
\hline Cabo Gata & 61198 & $02^{\circ} 20^{\prime} 23^{\prime \prime} \mathrm{W}$ & $36^{\circ} 34^{\prime} 12^{\prime \prime} \mathrm{N}$ & $1 \mathrm{~h}$ & $M B \& A D C P$ & 3 & $T, S$, Currents \\
\hline Alcudia & & $03^{\circ} 08^{\prime} 21^{\prime \prime} \mathrm{E}$ & $39^{\circ} 50^{\prime} 04^{\prime \prime} \mathrm{N}$ & $1 \mathrm{~h}$ & TG & 0 & SSH \\
\hline Algeciras & & $05^{\circ} 23^{\prime} 53^{\prime \prime} \mathrm{W}$ & $36^{\circ} 10^{\prime} 36^{\prime \prime} \mathrm{N}$ & $1 \mathrm{~h}$ & TG & 0 & SSH \\
\hline Almeria & & $02^{\circ} 28^{\prime} 41^{\prime \prime} \mathrm{W}$ & $36^{\circ} 49^{\prime} 47^{\prime \prime} \mathrm{N}$ & $1 \mathrm{~h}$ & TG & 0 & $\mathrm{SSH}$ \\
\hline Barcellona & & $02^{\circ} 09^{\prime} 48^{\prime \prime} \mathrm{E}$ & $41^{\circ} 20^{\prime} 30^{\prime \prime} \mathrm{N}$ & $1 \mathrm{~h}$ & TG & 0 & SSH \\
\hline Formentera & & $01^{\circ} 25^{\prime} 08^{\prime \prime} \mathrm{E}$ & $38^{\circ} 44^{\prime} 04^{\prime \prime} \mathrm{N}$ & $1 \mathrm{~h}$ & TG & 0 & SSH \\
\hline Gandia & & $00^{\circ} 09^{\prime} 06^{\prime \prime} \mathrm{W}$ & $38^{\circ} 59^{\prime} 44^{\prime \prime} \mathrm{N}$ & $1 \mathrm{~h}$ & TG & 0 & $\mathrm{SSH}$ \\
\hline Ibiza & & $01^{\circ} 26^{\prime} 58^{\prime \prime} \mathrm{E}$ & $38^{\circ} 54^{\prime} 39^{\prime \prime} \mathrm{N}$ & $1 \mathrm{~h}$ & TG & 0 & SSH \\
\hline Mahon & & $04^{\circ} 16^{\prime} 14^{\prime \prime} \mathrm{E}$ & $39^{\circ} 53^{\prime} 35^{\prime \prime} \mathrm{N}$ & $1 \mathrm{~h}$ & TG & 0 & SSH \\
\hline Malaga & & $04^{\circ} 24^{\prime} 51^{\prime \prime} W$ & $36^{\circ} 42^{\prime} 50^{\prime \prime} \mathrm{N}$ & $1 \mathrm{~h}$ & TG & 0 & $\mathrm{SSH}$ \\
\hline Melilla & & $02^{\circ} 55^{\prime} 41^{\prime \prime} \mathrm{W}$ & $35^{\circ} 17^{\prime} 26^{\prime \prime} \mathrm{N}$ & $1 \mathrm{~h}$ & TG & 0 & SSH \\
\hline Motril & & $03^{\circ} 31^{\prime} 24^{\prime \prime} \mathrm{W}$ & $36^{\circ} 43^{\prime} 11^{\prime \prime} \mathrm{N}$ & $1 \mathrm{~h}$ & TG & 0 & SSH \\
\hline Palma de Mallorca & & $02^{\circ} 38^{\prime} 15^{\prime \prime} \mathrm{E}$ & $39^{\circ} 33^{\prime} 37^{\prime \prime} \mathrm{N}$ & $1 \mathrm{~h}$ & TG & 0 & SSH \\
\hline Sagunto & & $00^{\circ} 12^{\prime} 21^{\prime \prime} \mathrm{W}$ & $39^{\circ} 38^{\prime} 02^{\prime \prime} \mathrm{N}$ & $1 \mathrm{~h}$ & TG & 0 & SSH \\
\hline Tarifa & & $05^{\circ} 36^{\prime} 12^{\prime \prime} \mathrm{W}$ & $36^{\circ} 00^{\prime} 23^{\prime \prime} \mathrm{N}$ & $1 \mathrm{~h}$ & TG & 0 & SSH \\
\hline Valencia & & $00^{\circ} 18^{\prime} 39^{\prime \prime} W$ & $39^{\circ} 26^{\prime} 30^{\prime \prime} \mathrm{N}$ & $1 \mathrm{~h}$ & $\mathrm{TG}$ & 0 & SSH \\
\hline \multirow[t]{2}{*}{ Portomaso } & & $14^{\circ} 29^{\prime} 41^{\prime \prime} \mathrm{E}$ & $35^{\circ} 55^{\prime} 17^{\prime \prime} \mathrm{N}$ & $1 \mathrm{~h}$ & MB & 3 & $T$ \\
\hline & & & & & TG & 0 & SSH \\
\hline
\end{tabular}

9, 1813-1851, 2012

\section{Mediterranean Monitoring and Forecasting Centre products}

M. Tonani et al.

Title Page

Abstract

Introduction

Conclusions

References

Tables

Figures
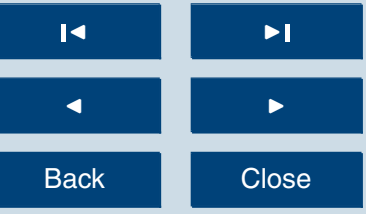

Back

Close

Full Screen / Esc

Printer-friendly Version

Interactive Discussion 
Table 2. List of collaborating institutes (in alphabetical order) providing NRT sub-regional ocean forecasts and/or analyses.

\begin{tabular}{|c|c|c|c|c|c|}
\hline MODEL & VARIABLE & DOMAIN & HOR. GRID & LEVELS & AN/FC \\
\hline SCRMFS (CNR-IAMC) & $\begin{array}{l}\text { Temperature }\left[{ }^{\circ} \mathrm{C}\right] \\
\text { Sea Surface Height }[\mathrm{m}]\end{array}$ & $\begin{array}{l}9^{\circ} \mathrm{E}-17^{\circ} \mathrm{E} \\
31^{\circ} \mathrm{N}-39.5^{\circ} \mathrm{N}\end{array}$ & $\begin{array}{l}1 / 32^{\circ} \text { Finite } \\
\text { differences }\end{array}$ & 30 sigma layers & AN \\
\hline WMRMFS (CNR-IAMC) & $\begin{array}{l}\text { Temperature }\left[{ }^{\circ} \mathrm{C}\right] \\
\text { Salinity }[\mathrm{PSU}] \\
\text { Sea Surface Height }[\mathrm{m}]\end{array}$ & $\begin{array}{l}3^{\circ} \mathrm{E}-16^{\circ} \mathrm{E} \\
36.7^{\circ} \mathrm{N}-44.5^{\circ} \mathrm{N}\end{array}$ & $\begin{array}{l}1 / 32^{\circ} \text { Finite } \\
\text { differences }\end{array}$ & 30 sigma layers & AN \\
\hline POSEIDON (HCMR) & $\begin{array}{l}\text { Temperature }\left[{ }^{\circ} \mathrm{C}\right] \\
\text { Salinity }[\mathrm{PSU}] \\
\text { Eastward Sea Water } \\
\text { Velocity }\left[\mathrm{m} \mathrm{s}^{-1}\right] \\
\text { Northward Sea Water } \\
\text { Velocity }\left[\mathrm{m} \mathrm{s}^{-1}\right]\end{array}$ & $\begin{array}{l}19.5^{\circ} \mathrm{E}-30^{\circ} \mathrm{E} \\
30.4^{\circ} \mathrm{N}-41^{\circ} \mathrm{N}\end{array}$ & $\begin{array}{l}1 / 30^{\circ} \text { Finite } \\
\text { differences }\end{array}$ & 25 sigma layers & $\mathrm{FC}$ \\
\hline MFS (INGV) & $\begin{array}{l}\text { Temperature }\left[^{\circ} \mathrm{C}\right] \\
\text { Salinity }[\mathrm{PSU}] \\
\text { Sea Surface Height }[\mathrm{m}] \\
\text { Eastward Sea Water } \\
\text { Velocity }\left[\mathrm{m} \mathrm{s}^{-1}\right] \\
\text { Northward Sea Water } \\
\text { Velocity }\left[\mathrm{m} \mathrm{s}^{-1}\right]\end{array}$ & $\begin{array}{l}6^{\circ} \mathrm{W}-36.25^{\circ} \mathrm{E} \\
30.19^{\circ} \mathrm{N}-45.94^{\circ} \mathrm{N}\end{array}$ & $\begin{array}{l}1 / 16^{\circ} \text { Finite } \\
\text { differences }\end{array}$ & 71 z layers & $\mathrm{AN}, \mathrm{FC}$ \\
\hline NAPON (NIB) & $\begin{array}{l}\text { Temperature }\left[{ }^{\circ} \mathrm{C}\right] \\
\text { Salinity }[\mathrm{PSU}] \\
\text { Sea Surface Height }[\mathrm{m}] \\
\text { Eastward Sea Water } \\
\text { Velocity }\left[\mathrm{m} \mathrm{s}^{-1} \text { ] }\right. \\
\text { Northward Sea Water } \\
\text { Velocity }\left[\mathrm{m} \mathrm{s}^{-1} \text { ] }\right.\end{array}$ & $\begin{array}{l}12.20^{\circ} \mathrm{E}-13.96^{\circ} \mathrm{E} \\
44.47^{\circ} \mathrm{N}-45.82^{\circ} \mathrm{N}\end{array}$ & $\begin{array}{l}600 \mathrm{~m} \text { Finite } \\
\text { differences }\end{array}$ & 11 sigma layers & FC \\
\hline ALERMO (NKUA) & $\begin{array}{l}\text { Temperature }\left[{ }^{\circ} \mathrm{C}\right] \\
\text { Salinity }[\mathrm{PSU}] \\
\text { Eastward Sea Water } \\
\text { Velocity }\left[\mathrm{m} \mathrm{s}^{-1} \text { ] }\right. \\
\text { Northward Sea Water } \\
\text { Velocity }\left[\mathrm{m} \mathrm{s}^{-1}\right]\end{array}$ & $\begin{array}{l}20^{\circ} \mathrm{E}-36.4^{\circ} \mathrm{E} \\
30.7^{\circ} \mathrm{N}-41.2^{\circ} \mathrm{N}\end{array}$ & $\begin{array}{l}2 \mathrm{Km} \text { Finite } \\
\text { differences }\end{array}$ & 25 sigma layers & AN,FC \\
\hline CYCOFOS (OC-UCY) & $\begin{array}{l}\text { Temperature }\left[{ }^{\circ} \mathrm{C}\right] \\
\text { Salinity }[\mathrm{PSU}] \\
\text { Sea Surface Height }[\mathrm{m}]\end{array}$ & $\begin{array}{l}31^{\circ} \mathrm{E}-36^{\circ} \mathrm{E} \\
33^{\circ} \mathrm{N}-37^{\circ} \mathrm{N}\end{array}$ & $\begin{array}{l}1 \mathrm{Km} \text { Finite } \\
\text { differences }\end{array}$ & 24 sigma layers & FC \\
\hline SELIPS (IOLR) & $\begin{array}{l}\text { Eastward Sea Water } \\
\text { Velocity }\left[\mathrm{m} \mathrm{s}^{-1}\right] \\
\text { Northward Sea Water } \\
\text { Velocity }\left[\mathrm{m} \mathrm{s}^{-1}\right]\end{array}$ & $\begin{array}{l}31.4^{\circ} \mathrm{E}-35.44^{\circ} \mathrm{E} \\
31.05^{\circ} \mathrm{N}-33.7^{\circ} \mathrm{N}\end{array}$ & $\begin{array}{l}0.95 \mathrm{Km} \text { Finite } \\
\text { differences }\end{array}$ & 27 sigma layers & FC \\
\hline ROSARIO (UMT-IOI-POU) & $\begin{array}{l}\text { Temperature }\left[{ }^{\circ} \mathrm{C}\right] \\
\text { Sea Surface Height }[\mathrm{m}]\end{array}$ & $\begin{array}{l}13.81^{\circ} \mathrm{E}-14.94^{\circ} \mathrm{E} \\
35.43^{\circ} \mathrm{N}-37.21^{\circ} \mathrm{N}\end{array}$ & $\begin{array}{l}1 / 96^{\circ} \text { Finite } \\
\text { differences, }\end{array}$ & 20 sigma layers & $\mathrm{FC}$ \\
\hline
\end{tabular}

OSD

9, 1813-1851, 2012

\section{Mediterranean \\ Monitoring and \\ Forecasting Centre products}

M. Tonani et al.

Title Page

Abstract

Introduction

Conclusions

References

Tables

Figures

14

4

Back

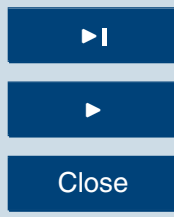

Full Screen / Esc

Printer-friendly Version

Interactive Discussion 
OSD

9, 1813-1851, 2012

\section{Mediterranean \\ Monitoring and \\ Forecasting Centre products}

Table 3. List of variables, supporting observations, and diagnostic for the Med-MFC evaluation.

\begin{tabular}{llll}
\hline Variables & Description & Supporting observations & Diagnostics \\
\hline Temperature & Time series and profile & Moored buoys, Satellite L4 SST & $\begin{array}{l}\text { RMS differences, and bias } \\
\text { at sensor depths }\end{array}$ \\
Sea-surface tem. & Time series & Moored buoys & $\begin{array}{l}\text { RMS differences, and bias } \\
\text { at sensor location }\end{array}$ \\
Salinity & Time series and profiles & Moored buoys & $\begin{array}{l}\text { RMS differences, and bias } \\
\text { at sensor }\end{array}$ \\
$\begin{array}{l}\text { Sea-surface height } \\
\text { Currents }(u, v)\end{array}$ & $\begin{array}{l}\text { Time series } \\
\text { Time series, profiles and } \\
\text { progressive vector diagram }\end{array}$ & $\begin{array}{l}\text { Tide gauge, Satellite L3 SLA } \\
\text { Moored buoys }\end{array}$ & $\begin{array}{l}\text { RMS differences } \\
\text { RMS differences, and bias } \\
\text { at sensor depths }\end{array}$ \\
\hline
\end{tabular}

M. Tonani et al.

Title Page

Abstract

Conclusions

Tables

14

4

Back

Introduction

References

Figures

Full Screen / Esc

Printer-friendly Version

Interactive Discussion 


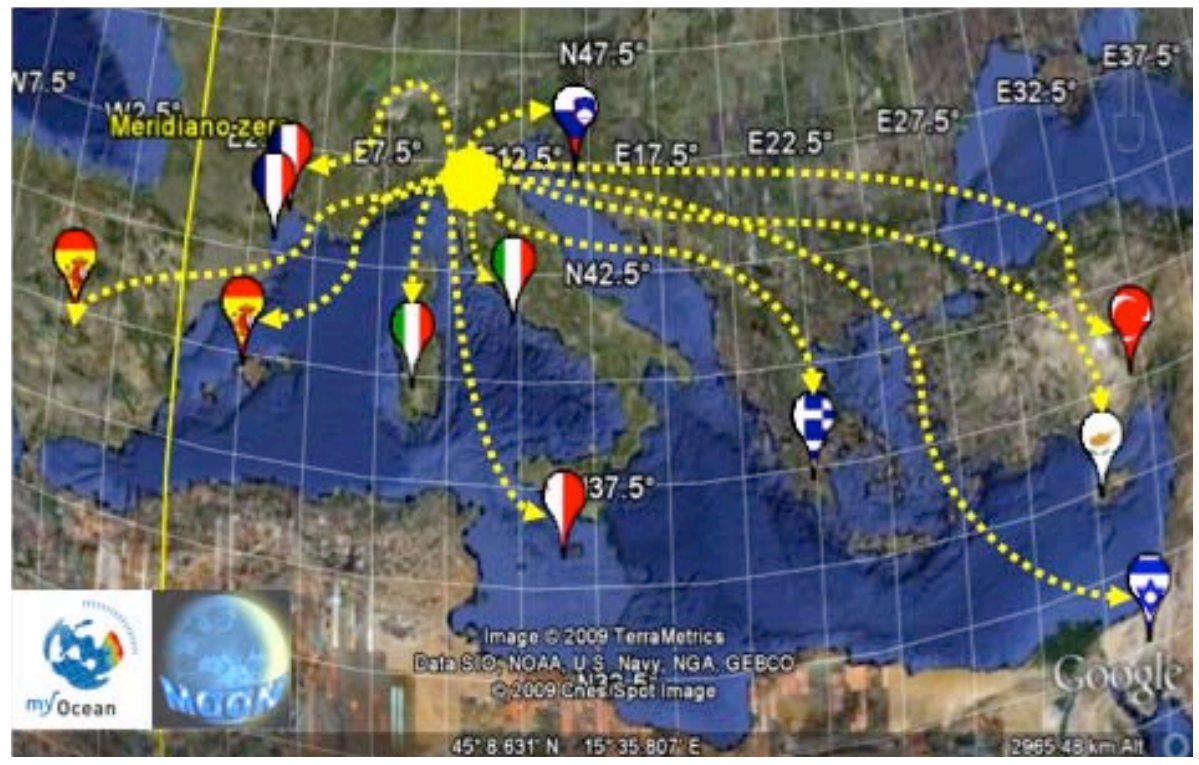

OSD

9, 1813-1851, 2012

\section{Mediterranean \\ Monitoring and \\ Forecasting Centre products}

M. Tonani et al.

Fig. 1. CalVal network, all the centre connected to INGV (yellow dot).

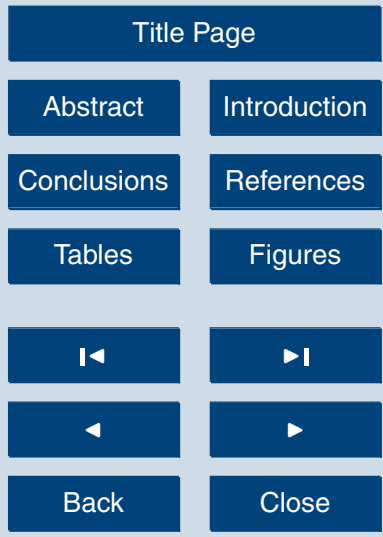

Full Screen / Esc

Printer-friendly Version

Interactive Discussion

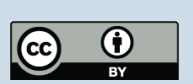




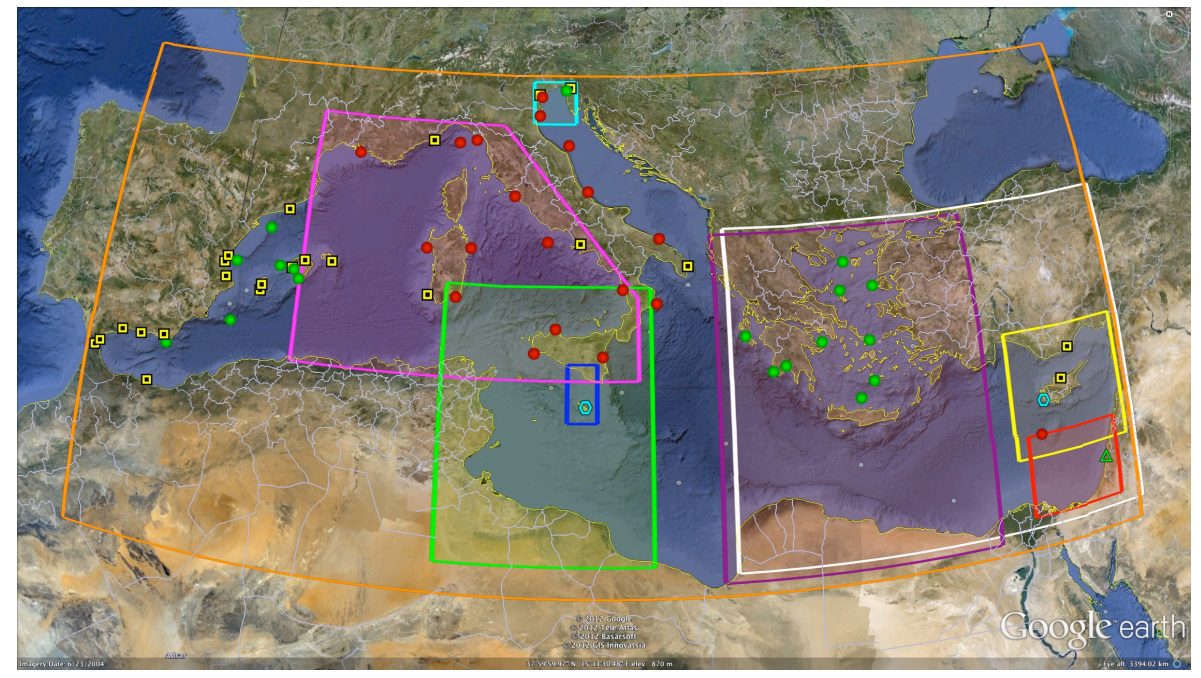

Fig. 2. Location of all the CalVal buoys and of all the sub-system forecasting systems. Different symbols indicate the type of observation provided by the buoy. The domain of the subregional nested systems is shown by the eight different polygons. Red-dot: moored buoy, green-dot: moored buoy and ADCP, yellow-black-square: tide gauge, green-triangle: ADCP, cyan-hexagon: moored buoy and tide gauge. The sub-systems are indicated by a polygonal contour line: Blu: ROSARIO (UMT-IOI-POU), Pink: WMRMFS (CNR-IAMC), green: SCRMFS (CNR-IAMC), white: ALERMO (NKUA), yellow: CYCOFOS (OC-UCY), cyan: NAPON (NIBMBS), purple: POSEIDON (HCMR), red: SELIPS (IOLR) and orange: Med-MFC (INGV).

\section{OSD}

$9,1813-1851,2012$

\section{Mediterranean \\ Monitoring and \\ Forecasting Centre products}

M. Tonani et al.

Title Page
Abstract

Conclusions

Tables

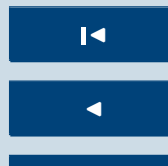

Back
Introduction

References

Figures

$>1$

$\rightarrow$

Close

\section{Full Screen / Esc}

Printer-friendly Version

Interactive Discussion 


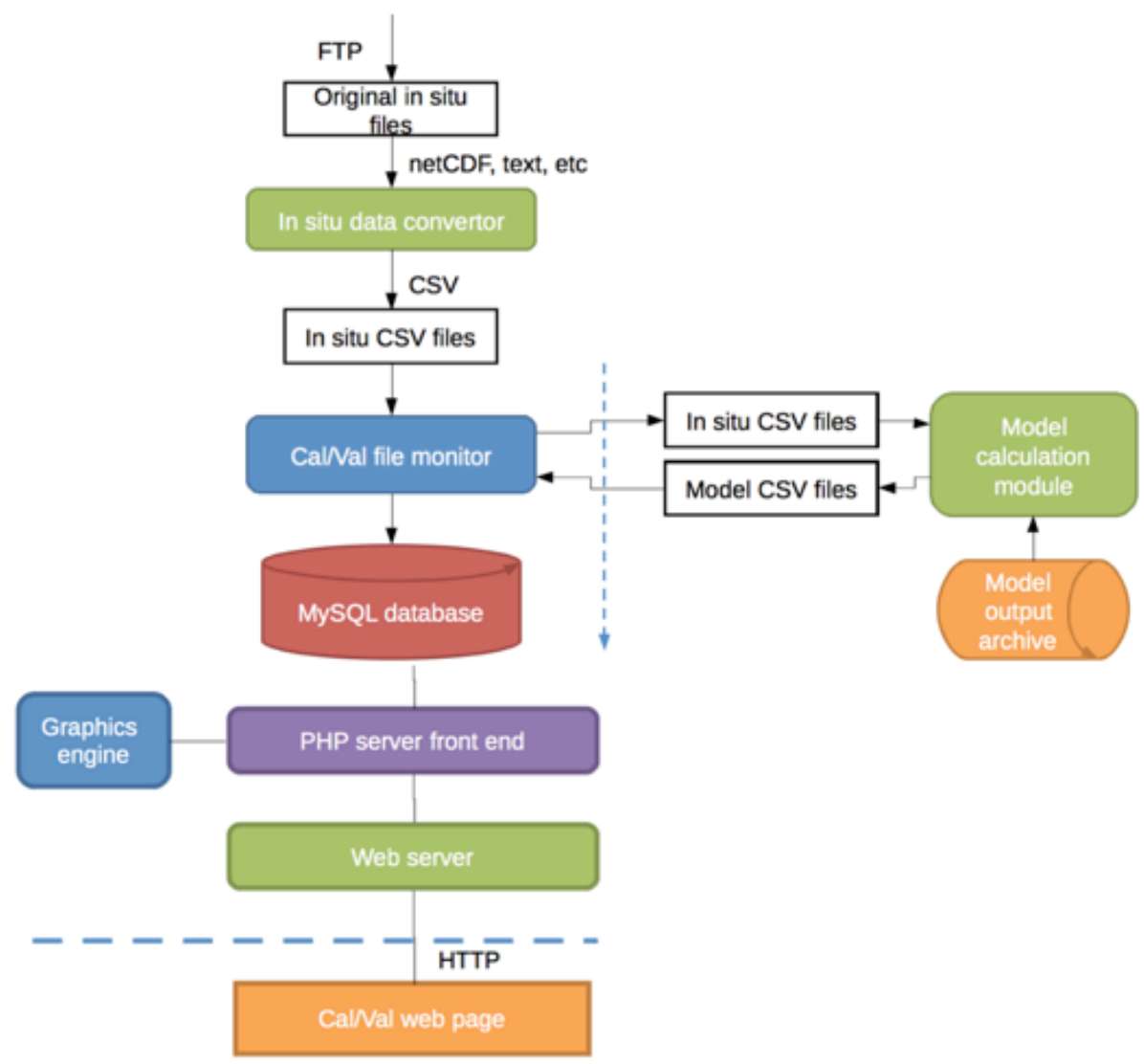

OSD

9, 1813-1851, 2012

\section{Mediterranean Monitoring and \\ Forecasting Centre products}

M. Tonani et al.

Title Page

Abstract

Introduction

Conclusions

References

Tables

Figures

14

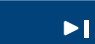

4

Back

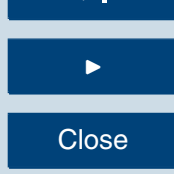

Full Screen / Esc

Fig. 3. CalVal network, database and web SW.

Printer-friendly Version

Interactive Discussion 
OSD

$9,1813-1851,2012$
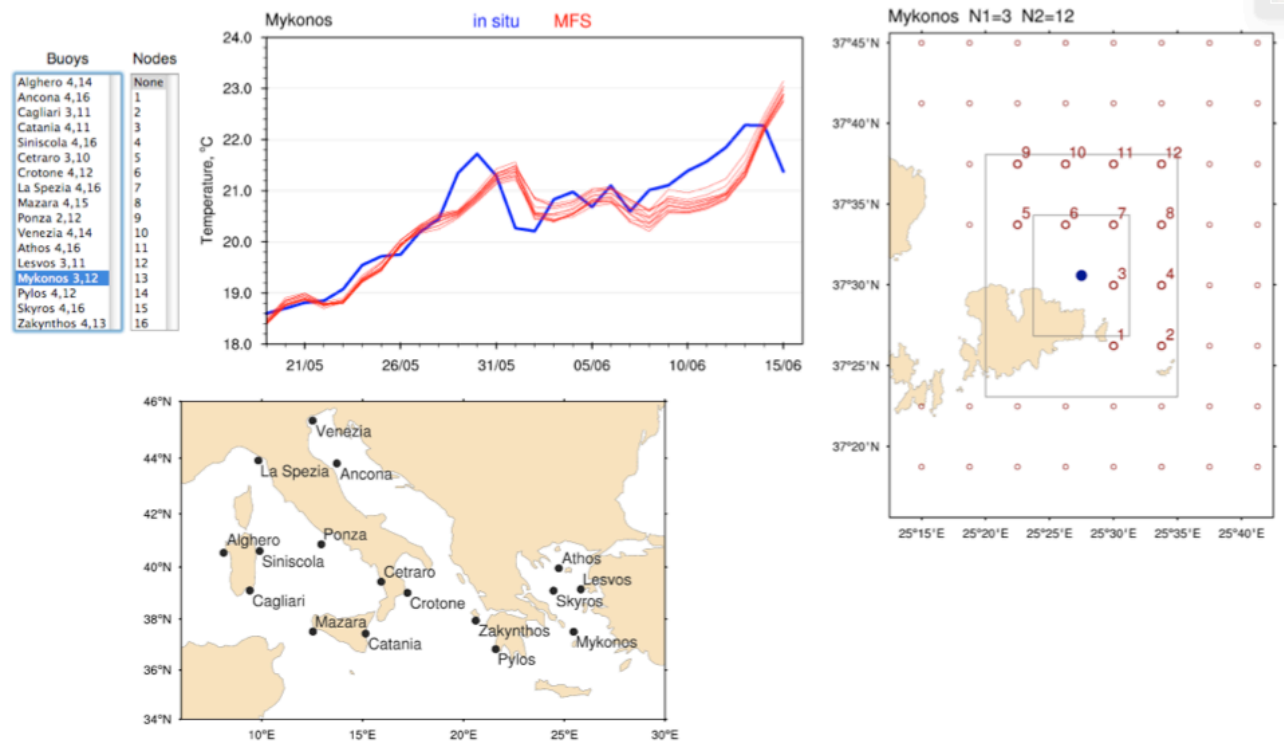

Fig. 4. Example of "missing" grid nodes, when the in-situ location is too close to the model domain boundaries in coastal areas. Buoy: Mykonos, Institute: HCMR (Greece), Variable: $T$, Depth: $3 \mathrm{~m}$. The model temperature values at all the numbered grid point of the right panel are shown in the top panel. The blue line is the buoy temperature. The map in the bottom panel shows the buoys location.

\section{Mediterranean Monitoring and Forecasting Centre products}

M. Tonani et al.

Title Page

Abstract Introduction

Conclusions

References

Tables

Figures

14

$\Delta$

4

Back

Close

Full Screen / Esc

Printer-friendly Version

Interactive Discussion 
OSD

$9,1813-1851,2012$

\section{Mediterranean Monitoring and \\ Forecasting Centre products}

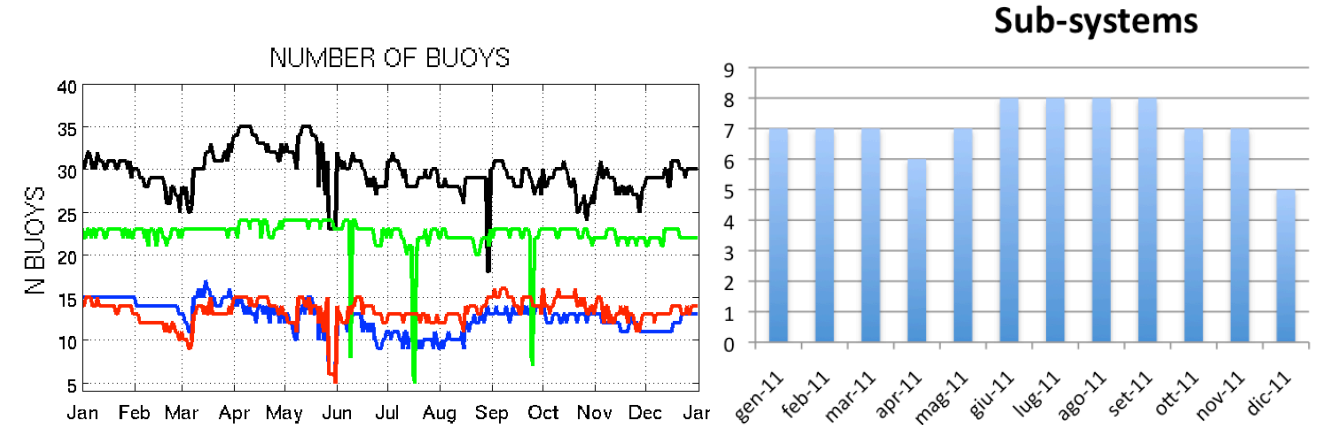

Fig. 5. Year 2011 statistics. Top panel: number of buoys available for temperature (dark line), Sea Level (green line), salinity (red line) and currents (blue line). Bottom panel: number of sub-systems forecasts provided each month of year 2011.

M. Tonani et al.

Title Page

Abstract Introduction

Conclusions

References

Tables

Figures

14

4

Back

Printer-friendly Version

Interactive Discussion
Close

Full Screen / Esc

sc 

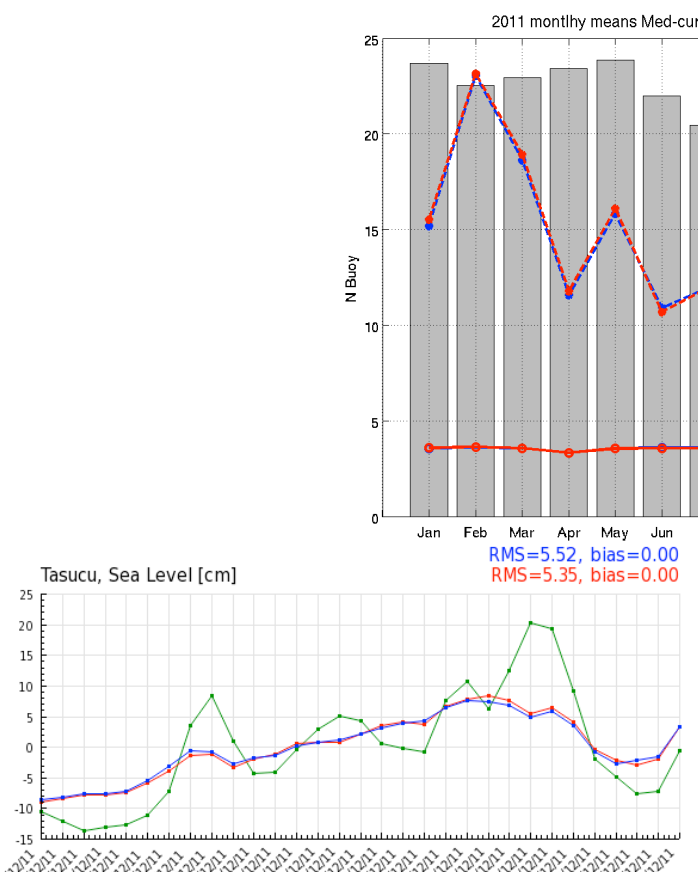

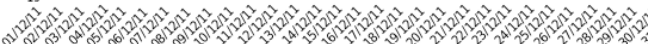

- In situ daily mean (average substracted)

- MFC Currents V1 AN (average substracted)

- MFC Currents V1 FC -3d (average substracted)

Fig. 6. Sea Level RMSE and bias. Top panel: monthly mean statistics for all the available buoys over year 2011. The bar represents the number of buoys used to compute the statistics for each month (left label). The red lines are the RMSE and Bias for Med-MFC AN (full line bias, dotted line RMSE), the blue lines are the RMSE and Bias for Med-MFC FC 3d (full line bias, dotted line RMSE). Bottom-left panel: comparison between the Tasucu Tide Gauge (IMS-METU) and the MFC-current AN and FC-3d for the month of December 2011. Bottom-right panel: comparison between Imperia Buoy (ISPRA) and MFC-current AN and WMRM sub-system for the month of February 2011.

\section{OSD}

9, 1813-1851, 2012

\section{Mediterranean \\ Monitoring and \\ Forecasting Centre products}

M. Tonani et al.

Title Page

Abstract

Introduction

Conclusions

References

Tables

Figures

14

4

Back

Close

Full Screen / Esc

Printer-friendly Version

Interactive Discussion 


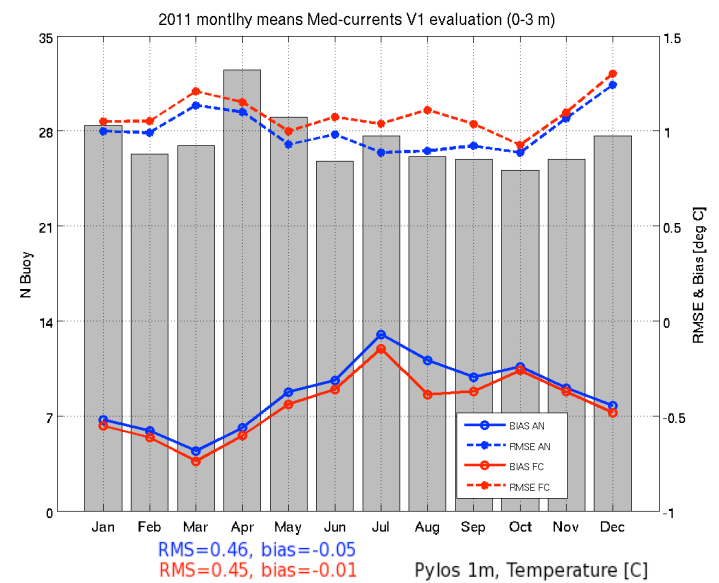

OSD

$9,1813-1851,2012$

\section{Mediterranean \\ Monitoring and \\ Forecasting Centre products}

M. Tonani et al.

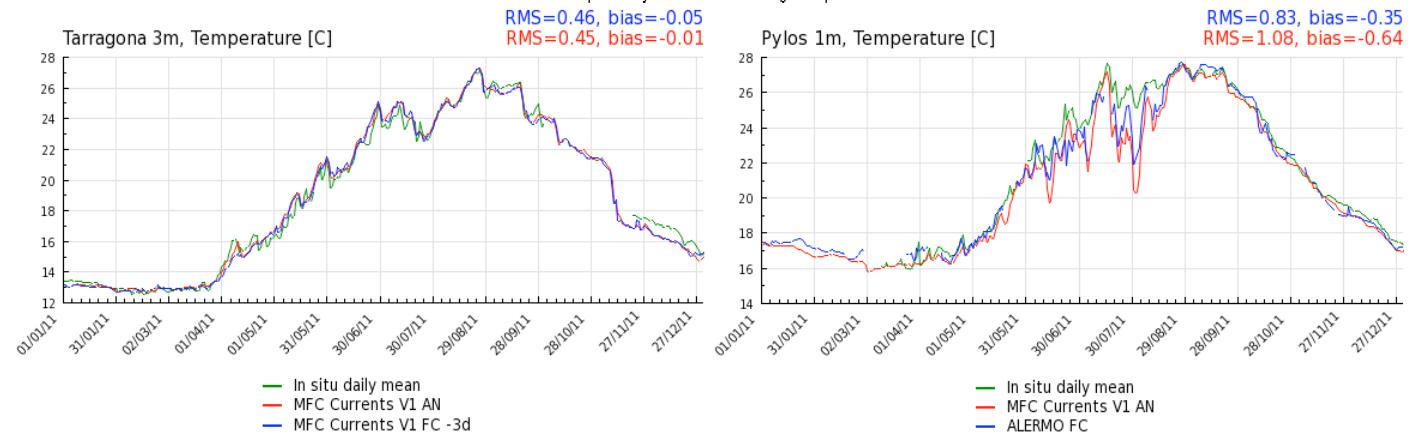

Fig. 7. Temperature between 1 and $3 \mathrm{~m}$ depth. Top panel: monthly mean statistics for all the available buoys over year 2011. The bar represents the number of buoys used to compute the statistics for each month (left label). The red lines are the RMSE and Bias for Med-MFC AN (full line bias, dotted line RMSE), the blue lines are the RMSE and Bias for Med-MFC FC 3d (full line bias, dotted line RMSE). Bottom-left panel: comparison between the Terragona buoy (Puertos del Estado) and MFC-currents AN and FC-3d for all the year 2011. Bottom-right panel: comparison between the Pylos (HCMR, Greece) buoy and the MFC-currents and the ALERMO sub-system for year 2011.

Title Page

Abstract

Introduction

Conclusions

References

Tables

Figures

14

4

Back

Close

Full Screen / Esc

Printer-friendly Version

Interactive Discussion 
Cabo de Palos 3m, Salinity [PSU]
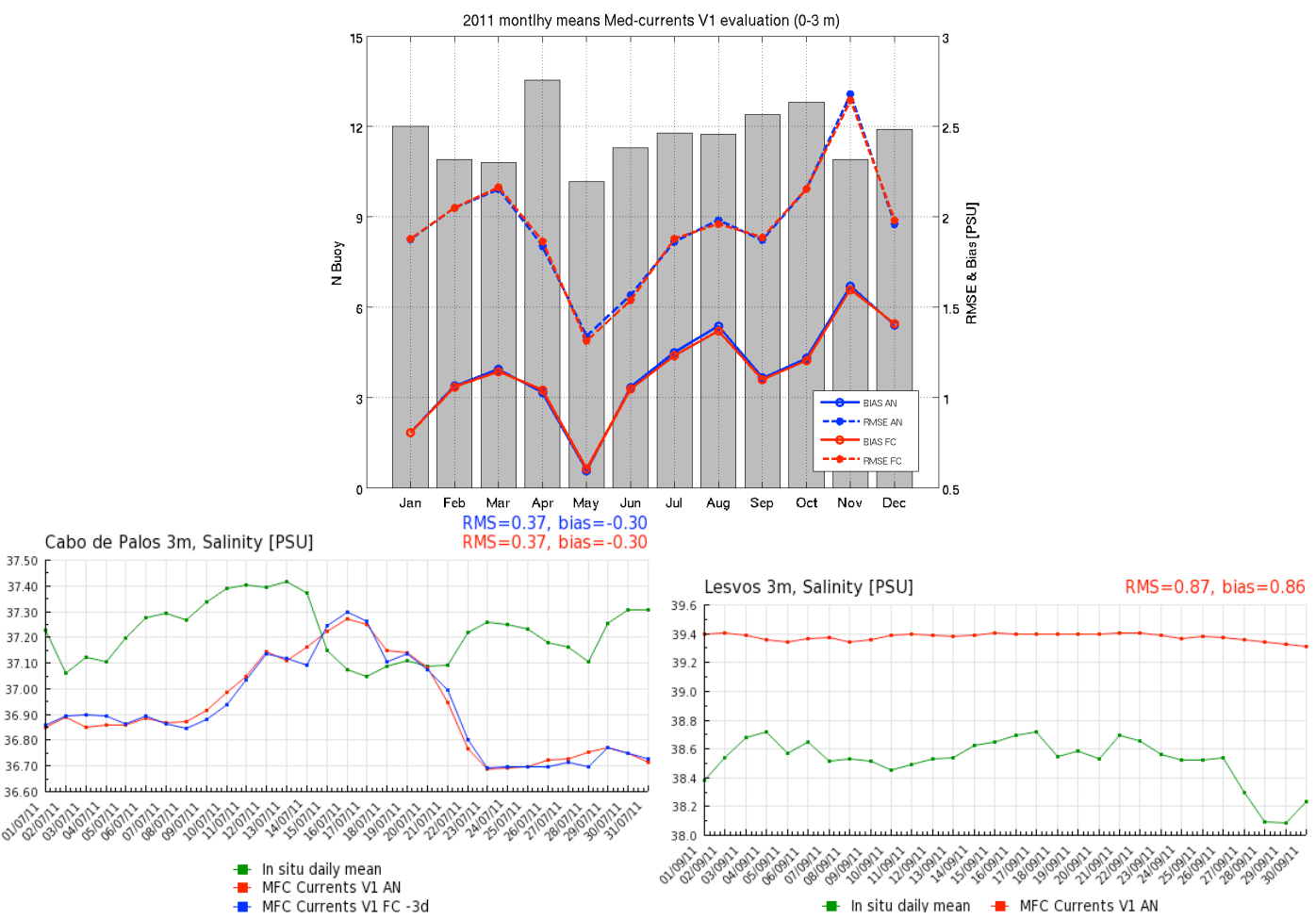

Fig. 8. Salinity between 1 and $3 \mathrm{~m}$ depth. Top panel: month mean statistics for all the available buoys over year 2011. The bar represents the number of buoys used to compute the statistics for each month (left label). The red lines are the RMSE and Bias for Med-MFC AN (full line bias, dotted line RMSE), the blue lines are the RMSE and Bias for Med-MFC FC 3d (full line bias, dotted line RMSE). Bottom-left panel: comparison between the Cabo de Palos buoy (Puertos del Estado) and MFC-currents AN and FC-3d for July 2011. Bottom-right panel: comparison between the Lesvos (HCMR) buoy and the MFC-currents for September 2011.

\section{OSD}

9, 1813-1851, 2012

\section{Mediterranean \\ Monitoring and \\ Forecasting Centre products}

M. Tonani et al.

Title Page

Abstract

Introduction

Conclusions

References

Tables

Figures

14

4

Back

Close

Full Screen / Esc

Printer-friendly Version

Interactive Discussion 
OSD

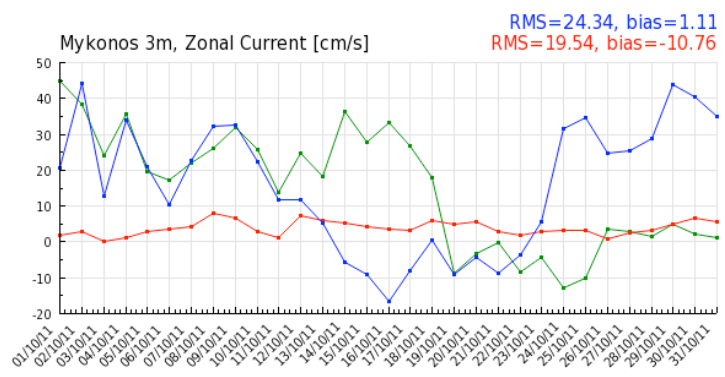

9, 1813-1851, 2012

- In situ daily mean

- MFC Currents
- POSEIDON FC

Distance $[\mathrm{km}]$

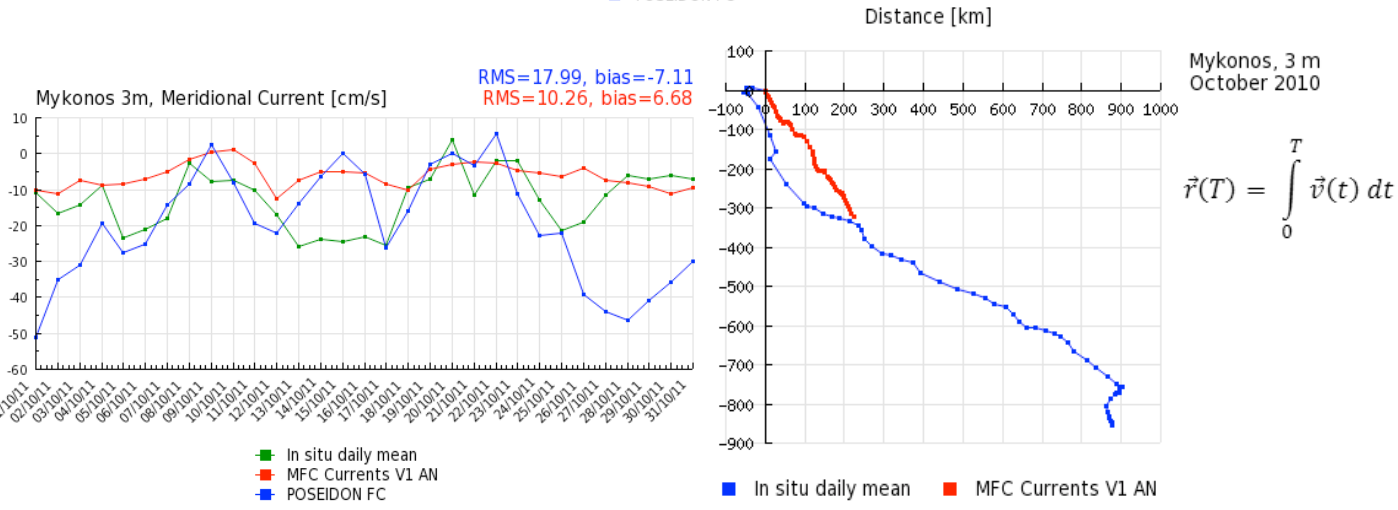

Fig. 9. Current field evaluation for October 2011 at the Mykonos station (HCMR). Top panel: zonal (left) and meridional (right) velocity field. The green line is the in-situ measurement; the red line is the Med-MFC AN and the blue line is the POSEIDON FC. Bottom panel: progressive vector diagram for the in-situ (blue) and MFS AN (red) velocity fields.

\section{Mediterranean Monitoring and Forecasting Centre products}

M. Tonani et al.

Title Page

Abstract Introduction

Conclusions References

Tables Figures
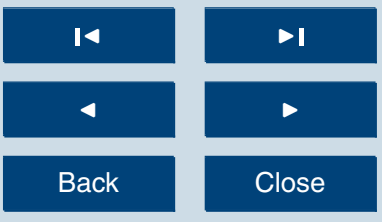

Back

Full Screen / Esc

Printer-friendly Version

Interactive Discussion 
OSD

$9,1813-1851,2012$
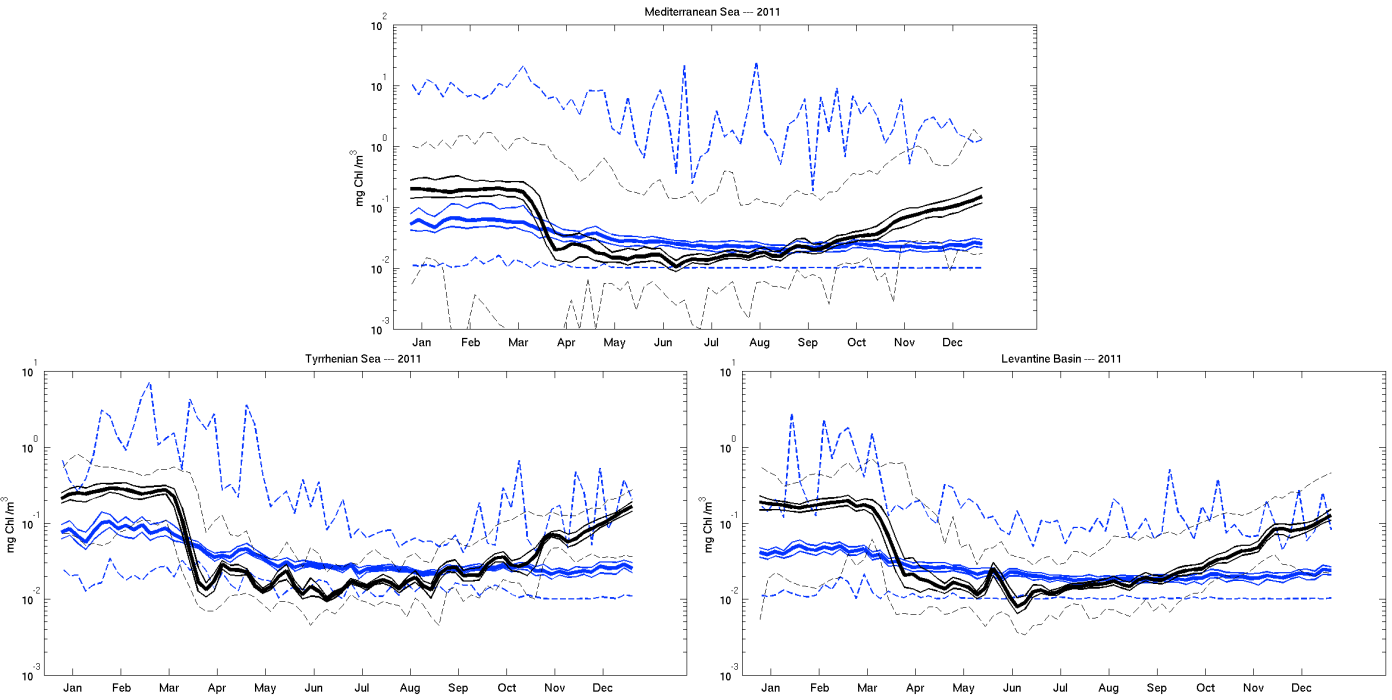

Fig. 10. Chlorophyll statistics for 2011, comparison between OPATM-BFM model forecast and Modis satellite observations from MyOcean OC-TAC. Satellite observations are described by blue lines, while forecast is described by the black ones. For both of them the 50th percentile is shown by the bold line, 25th and 75th percentile by the two continuous lines. Dashed lines plot minimum and maximum values. Top Panel: statistics for the Mediterranean Sea. Bottom panels: same statistics for sub-basins, Tyrrhenian Sea and Levantine Basin.

\section{Mediterranean Monitoring and Forecasting Centre products}

M. Tonani et al.

Title Page

Abstract

Conclusions

Tables

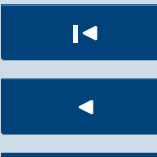

Back

Introduction

References

\section{Figures}

Full Screen / Esc

Printer-friendly Version

Interactive Discussion 